تطبيق المربين للتوصيات الفنية في مجال تربية ورعاية الأغنام في بعض قرى محافظة

\begin{abstract}
استهدف البحث بصفة أساسية التعرف على مستوى تطبيق المربين للتوصيات الفنية الموصى بها في مجال تربية ورعاية

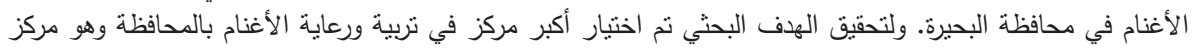

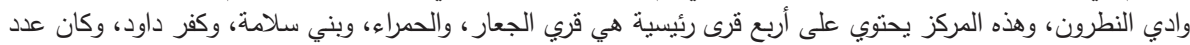

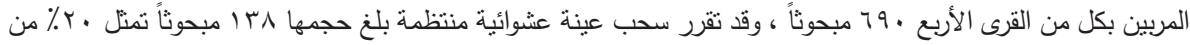

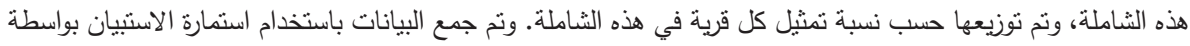

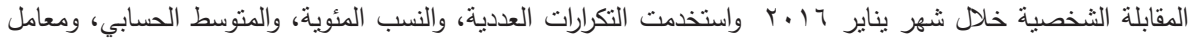

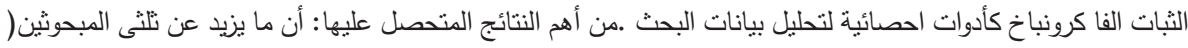

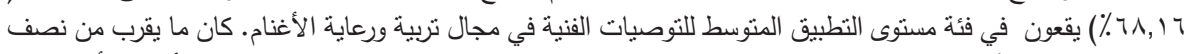

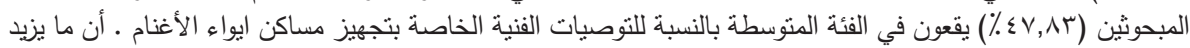

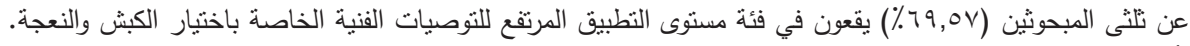

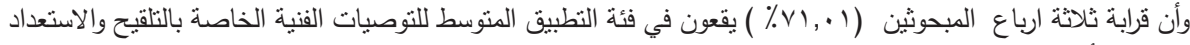

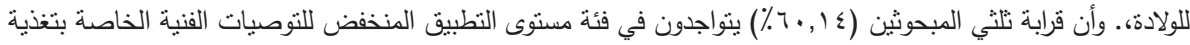

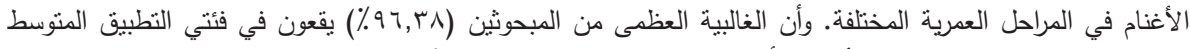

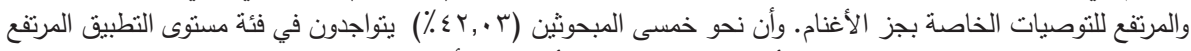

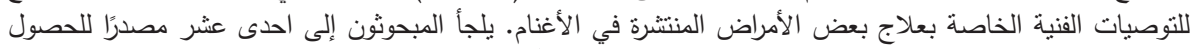

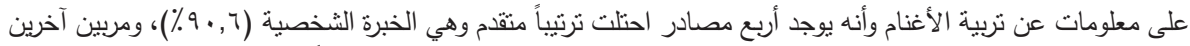

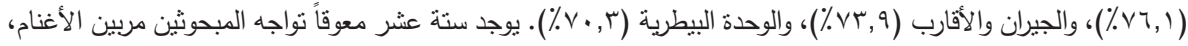

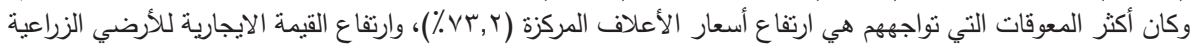

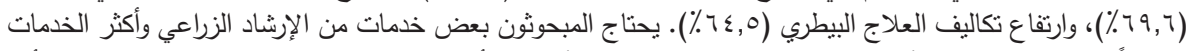

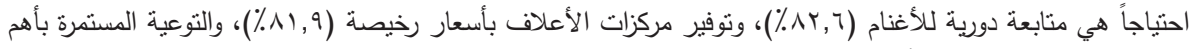

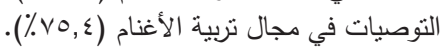

وقد توصل البحث إلى العديد من النتائج كان من أبرزها ما يلي :

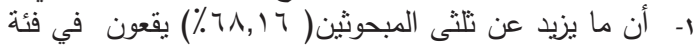

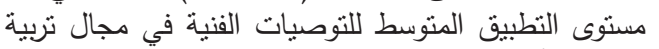

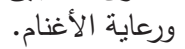

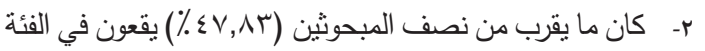

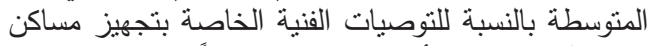

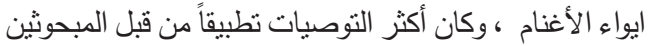

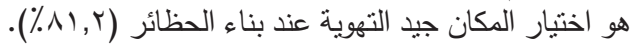

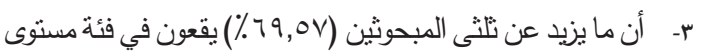
التطبيق المرتفع للتوصيات الفنية الخاصة باختيار الكبش والنعجة النئ،

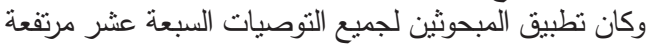

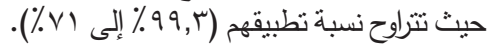

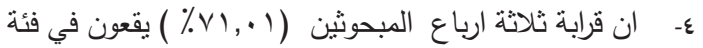

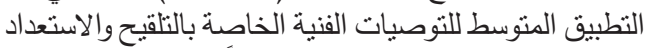

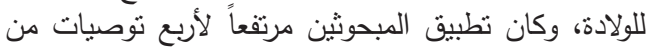

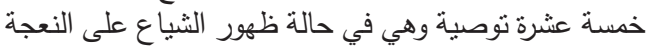

استهدف البحث بصفة أساسية التعرف على مستوى تطبيق المربين

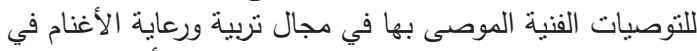
محافظة البحيرة. ولتحقيق الهدف البحثي تم اختيار أكبر مركز في في الإي

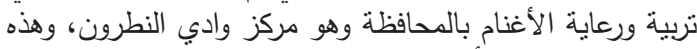

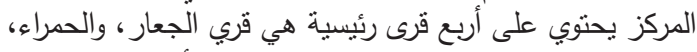

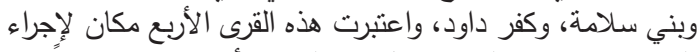

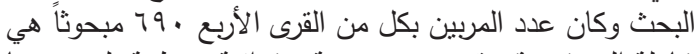

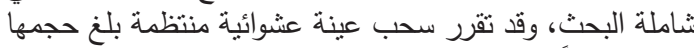

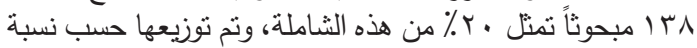

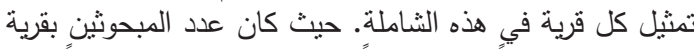

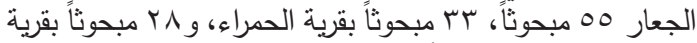
بني سلامة، و r r مبحوثاً بقرية كفر داود.

وتم جمع البيانات باستخدام استمارة الاستيان بواسطة المقابلة

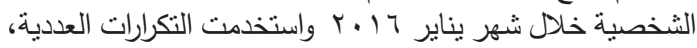

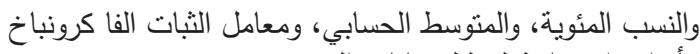
كأدوات احصائية لتحليل بيانات البحثي ل

*Corresponding author: aydesouky@yahoo.com

DOI : 10.21608/jsas.2018.5018.1090

C2018 National Information and Documentation Center (NIDOC) 


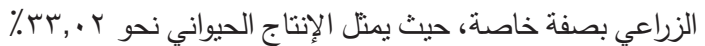

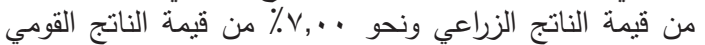

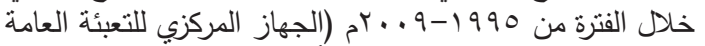

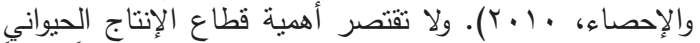

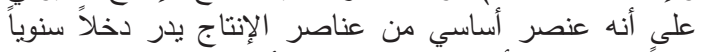

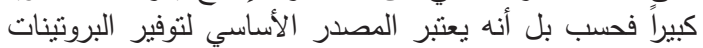

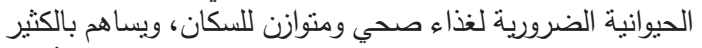

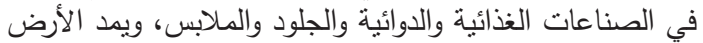

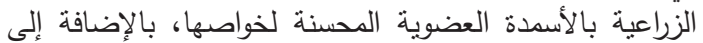

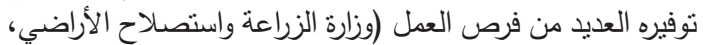

. (OV : r... 9

وعلى الرغم من الجهود الكبيرة والمكثفة التي يبذلها القائمين

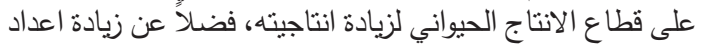

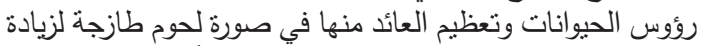

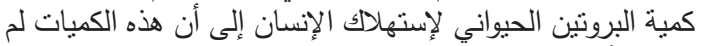

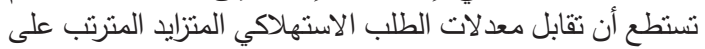

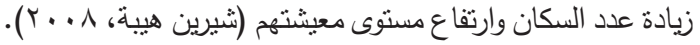

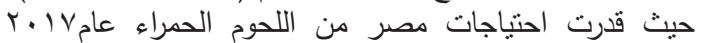

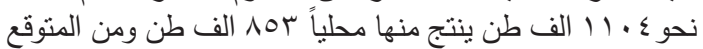

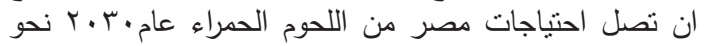

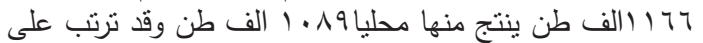

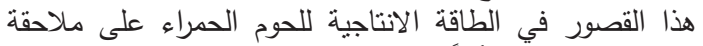

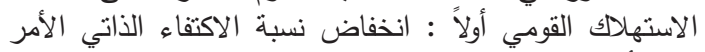

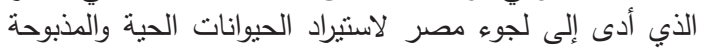

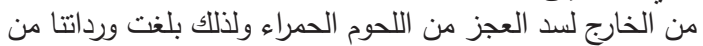

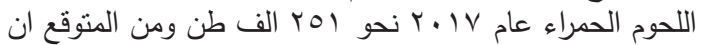

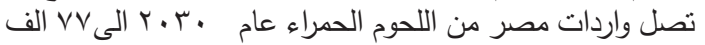

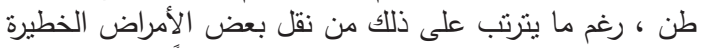

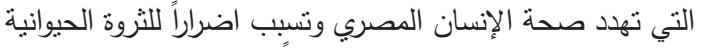

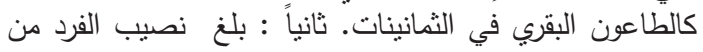

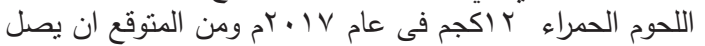

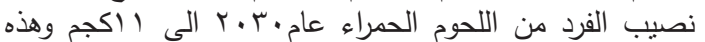

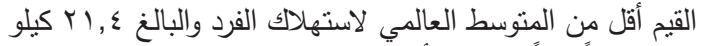

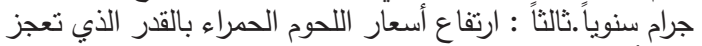

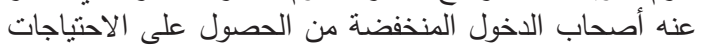

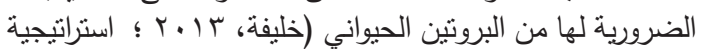

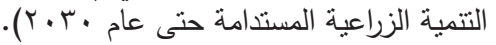

ومن أجل تحيق الاكتفاء الذاتي من اللحوم الحمراء وسد الأناء

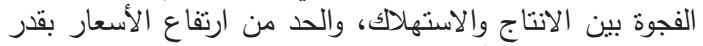

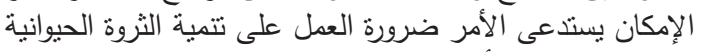

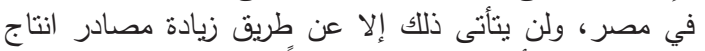

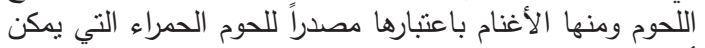

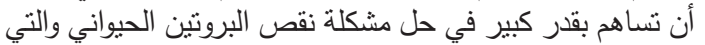

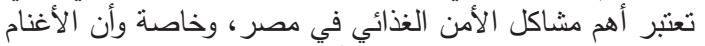

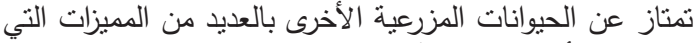
تجعلها من أحد الركائز الأساسية لتنمية الثروة الحية الحيوانية والتئى منها

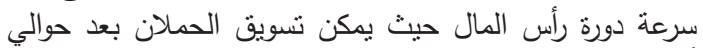

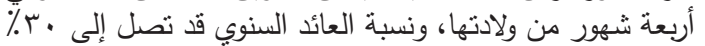

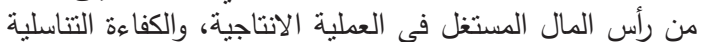

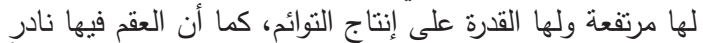

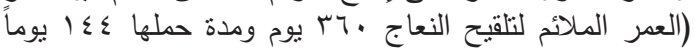

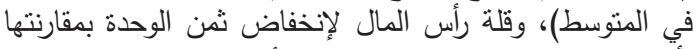

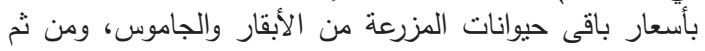

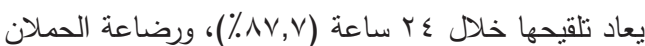

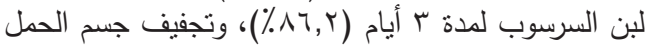

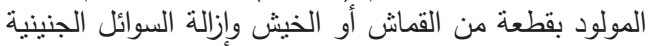

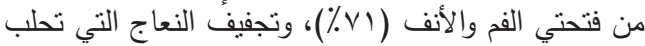

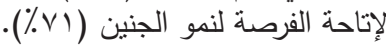

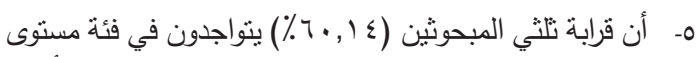
التطبيق المنخفض للتوصيات الفنية الخاصة بتغنية التخدية الأغنام

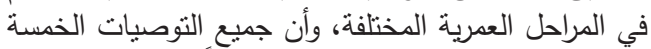

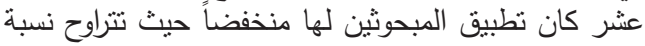

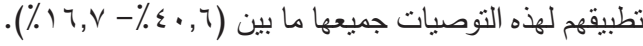

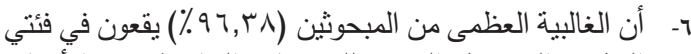

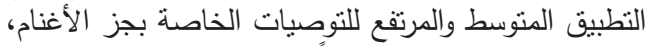
وكان تطبيق المبحوثين مرتفعاً لثلاثة توصيات من إجمات التياتي

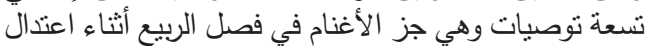

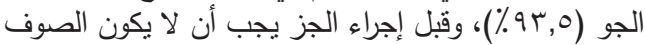

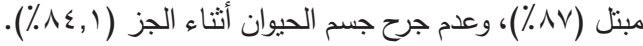

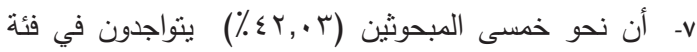
مستوى النطبيق المرتفع للتوصيات الفنية الخاصة بعن بعلاج

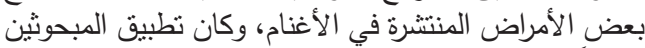

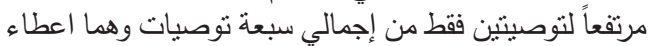

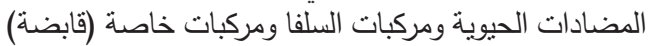

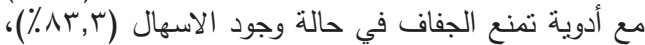

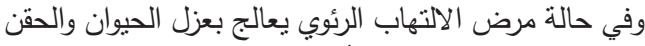

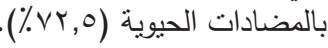

ي- يلجأ المبحوثون إلى احدى عشر مصدرًا للحصول على معلومات

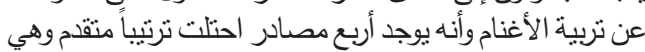

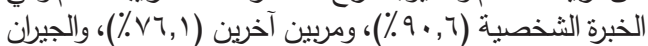
والأفارب (q, (

هـ يوجد ستة عشر معوقاً تواجه المبحوثين مربين الأغنام، وكان

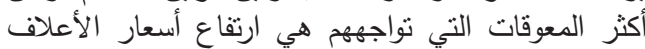

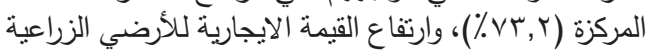

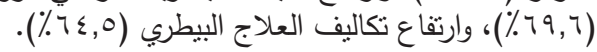

•- ا- يحتاج المبحوثون بعض خدمات من الإرشاد الزراعي وأكثر.

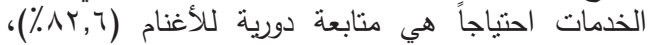

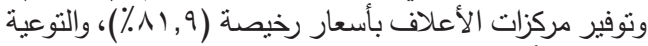

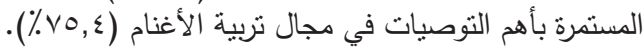

المقدمة والمشكلة البحثبة

يعد القطاع الزراعي أحد الركائز الأساسية للبنيان الاقتصادي

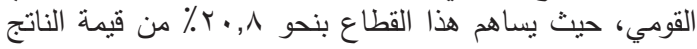

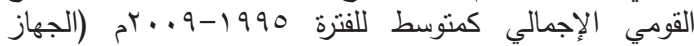

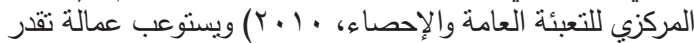

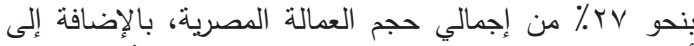

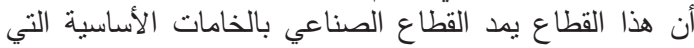

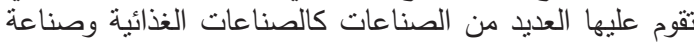

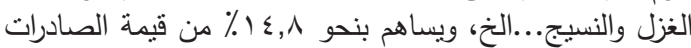

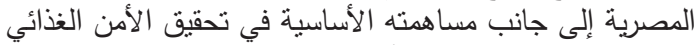
(وزارة الزراعة واسنصلاح الأراضي، • ( • (ب).

ويعنبر قطاع الانتاج الحيواني في مصر من القطاعات

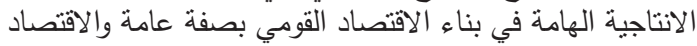

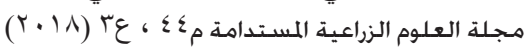




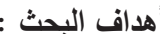

بستهدف البحث بصفة أساسية التعرف على مستوى تطبيق

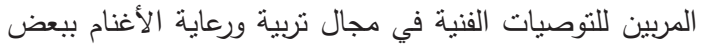
قرى محافظة البحيرة. ويتحقق ذلك من خلال : لرال

ا- التعرف على مستوى تطبيق المبحوثين للتوصيات الفنية في مجال تربية ورعاية الأغنام بمنطقة البحث.

r- التعرف على مصادر المعلومات التي يستعين بها المبحوثين في تربية ورعاية الأغنام مع تحديد أكثرها أهمية.

ب- تحديد المعوقات التي تواجه المبحوثين في مجال تربية ورعاية

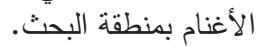

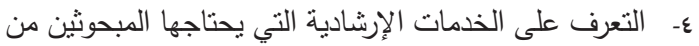
الإرشاد الزراعي وتحديد درجة احتياجهم إليها.

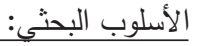

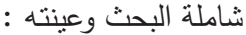

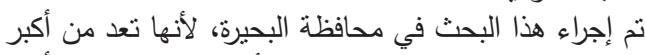

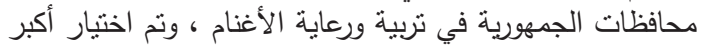

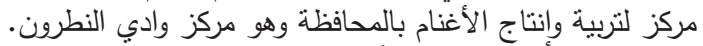
ويضم مركز وادى النطرون أربع قري رئيسية وهي قرية الأنية الجعار

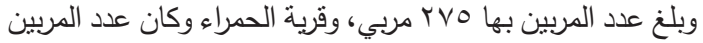

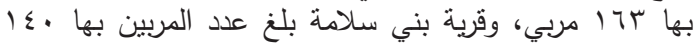

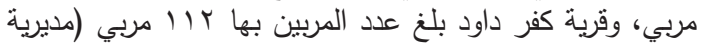

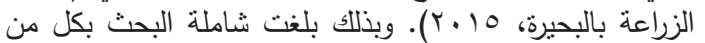

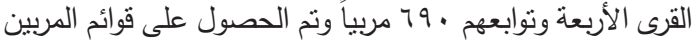
من سجلات حصر الانتاج الحيواني بمديرية الزراعة بالبحيرة البعائ.

وتم سحب عينة عشوائية منتظمة بلغ قوامها ربا مبا مبحوثاً

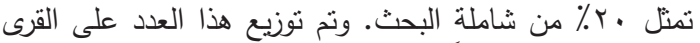

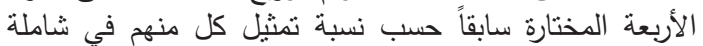

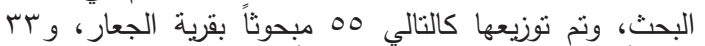

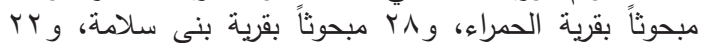
مبحوثاً بقرية كفر داود.

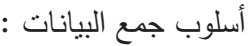

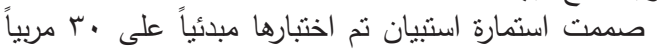

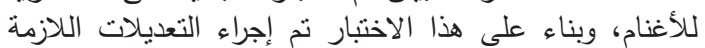

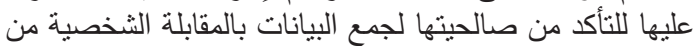

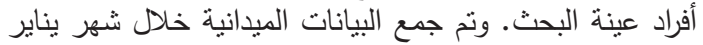

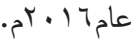

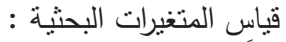
أولاً : قياس المتغيرات البغرات المسنقلة :

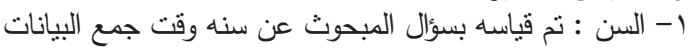

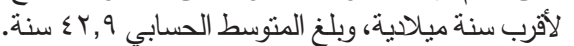

r- عدد سنوات التعليم : تم قياسه بعدد سنوات التعليم الرسمي التي

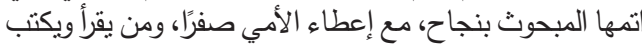
أربع درجات، وبلغ منتوسط عدد سنوات تعليم المبحوثين ^, آس سنة.

r- الخبرة في مجال تربية الأغنام : تم قياسه بالرقم الخام لعدد

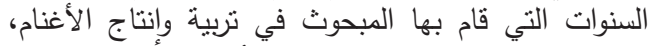

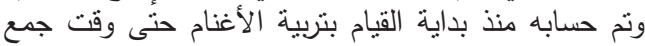

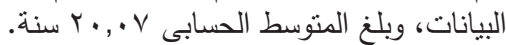

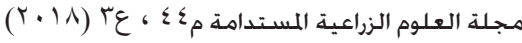

تكون المخاطرة بفقد الحيوان قليلة نسبياً، وكما أن لها مقدرة كبيرة

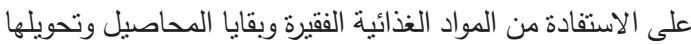

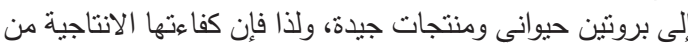

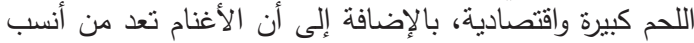

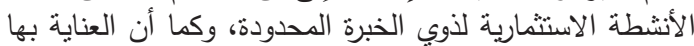

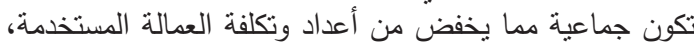

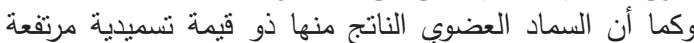

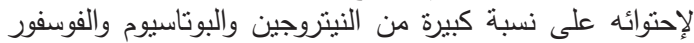

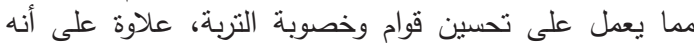

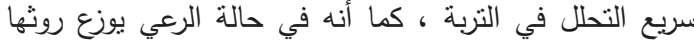

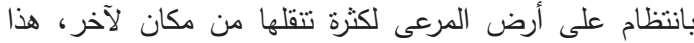

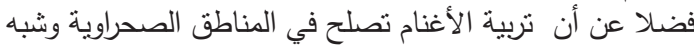

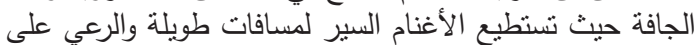

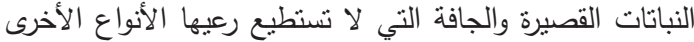

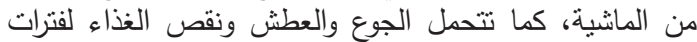

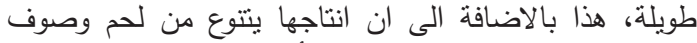

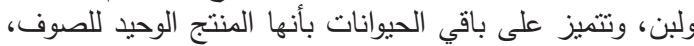

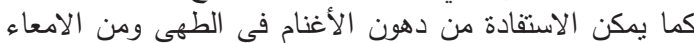

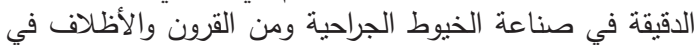

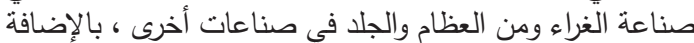

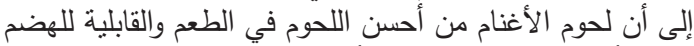

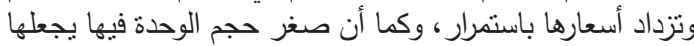

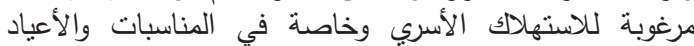

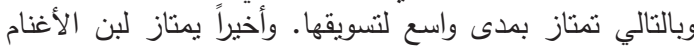

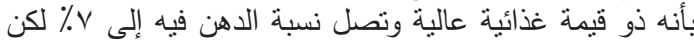

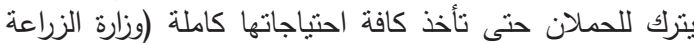

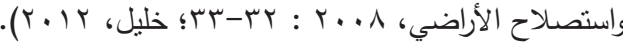

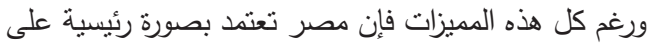

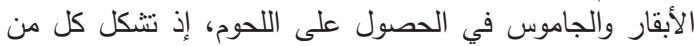

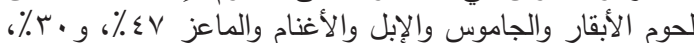

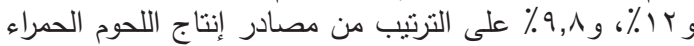

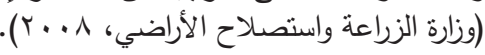

ونستنتج مما سبق عرضه أنه بالرغم من المميزات الهائلة

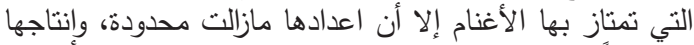

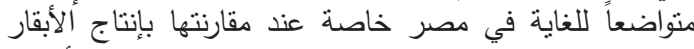

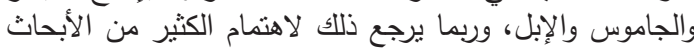

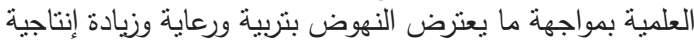

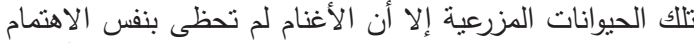
البحثي الذي حظيت به تلألك الحيوانات فالقليل من الإنيل الأبحاث

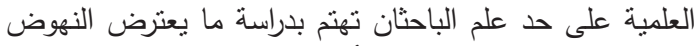

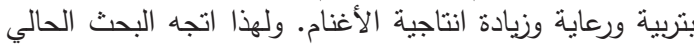

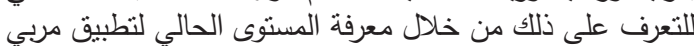

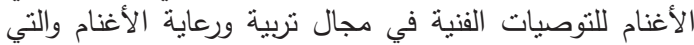

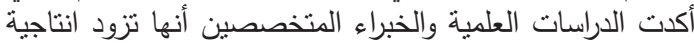

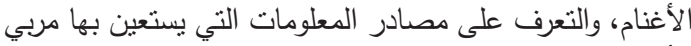

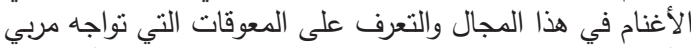

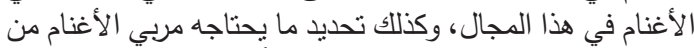

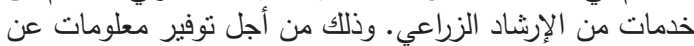

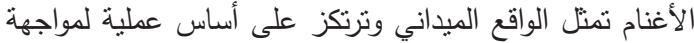

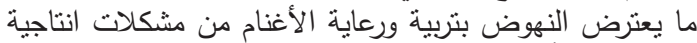
وصحية سعياً إلى الوصول بإنتاجية الأغنام إلى أقصى طانية طاقة

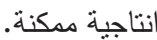


كل بعد منها تطبيث أحد التوصبات الفنبة في مجال نربية ورعاية

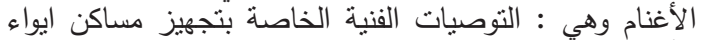

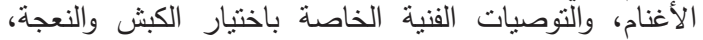

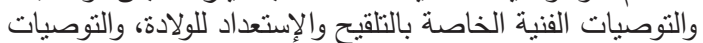

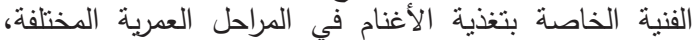

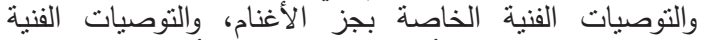

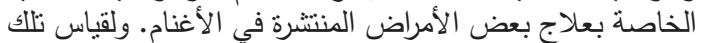

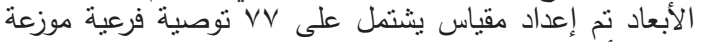
على الأبعاد الستة نم عرضها على الإنى الباحثين المختصين بمعهد

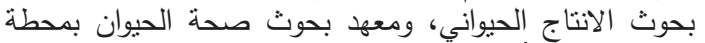

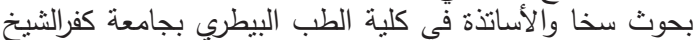

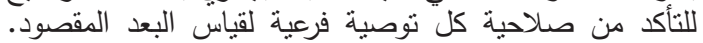

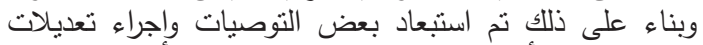

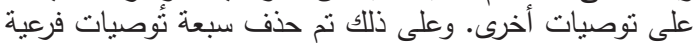

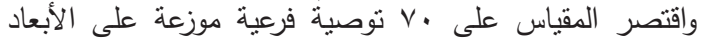

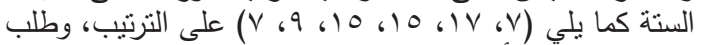

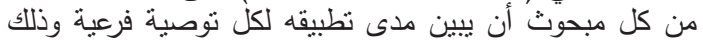

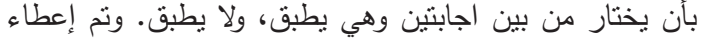

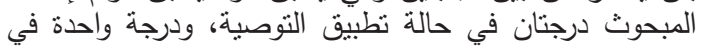

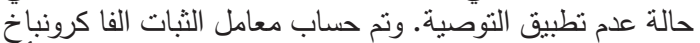

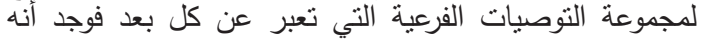

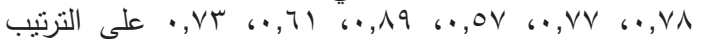

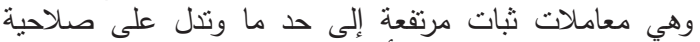

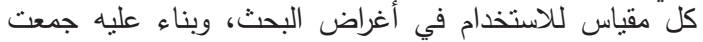

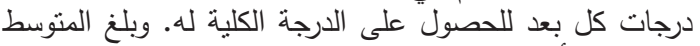

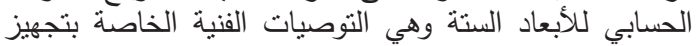

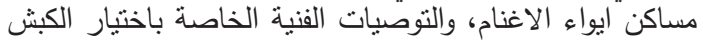

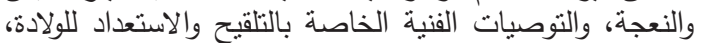

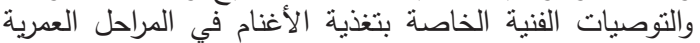

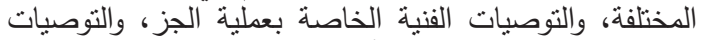

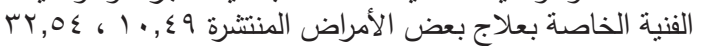

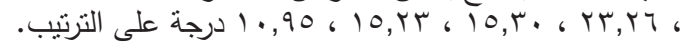

$$
\text { الأساليب الإحصائية المستخدمة : }
$$

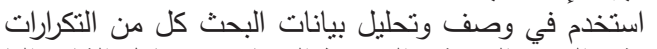

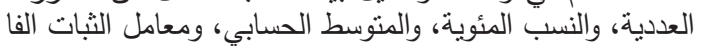
كرونباخ لبعض المتغيرات البحنية.

$$
\text { وصف خصائص عينة البحث : }
$$

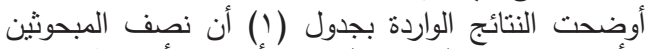

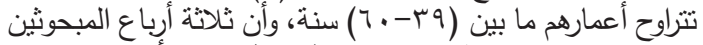

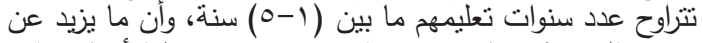
نصف المبحوثين كان عدد سنوات خبرتهم في نتربية الأغنام تتراوح

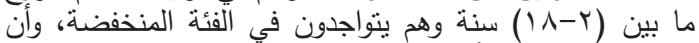

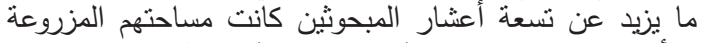

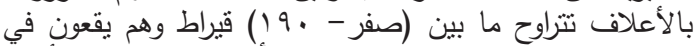
الفئة الصغيرة ، وربما برجع ذلاف للك إلى أن معظم مربين الأغنام

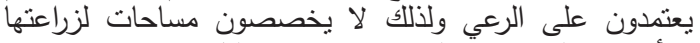

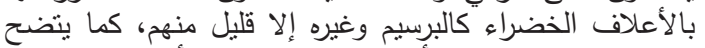

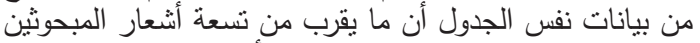

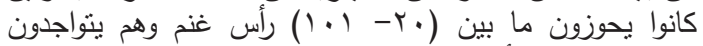

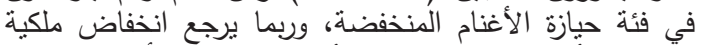

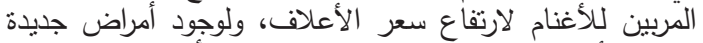

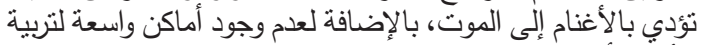

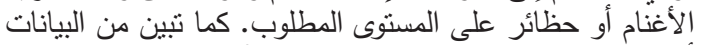

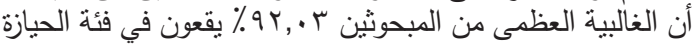

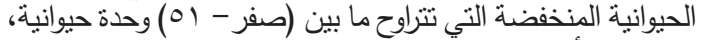

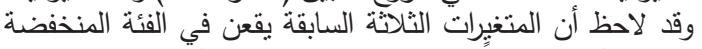

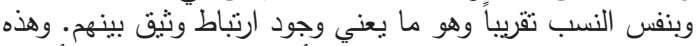

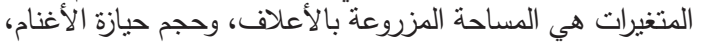

ع - المساحة المزروعة بالأعلاف : استخدمت الأرقام الخام المعبرة

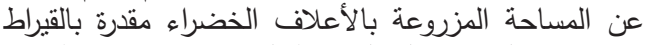

وقت إجراء البحث، وبلغ المتوسط الحسابي • , ل قيراط.

ه- حجم حبازة الأغنام : تم قياسها بعدد الأغنام التي يحوزها

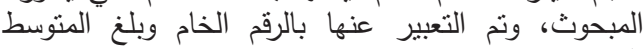
الحسابي 0, \؛ درجة.

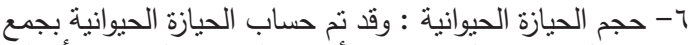
إجمالي حبازة الجاموس والأبقار والماعز ولثة والحمير ، وأعطي

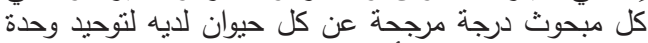

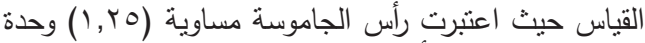

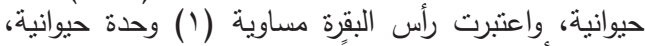

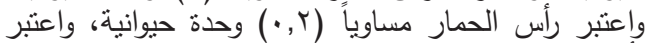

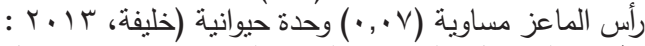

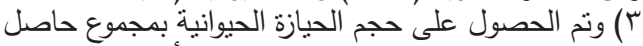

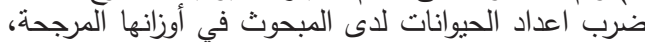

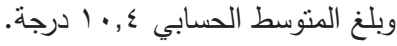

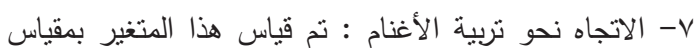

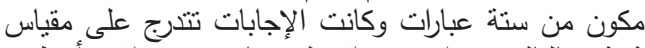

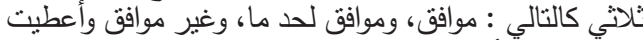

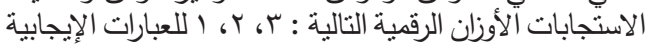

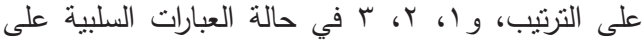

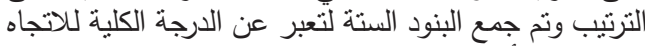

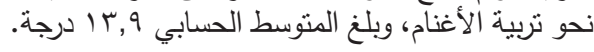

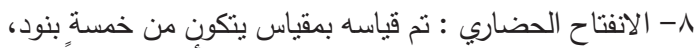

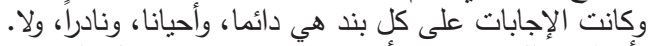

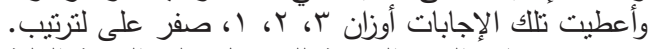

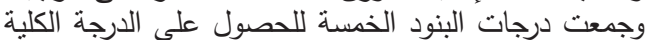
للانفتاح الحضاري، وكان متوسط درجات العينة ب, 11 1 درجة.

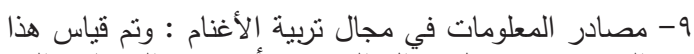

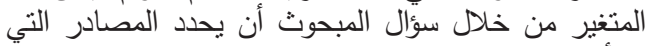

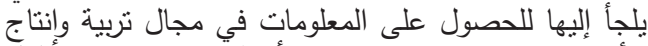

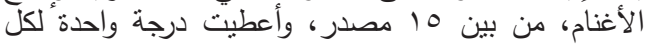

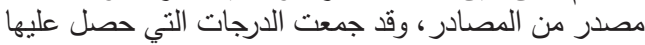

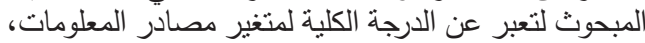
وبلغ المتوسط الحسابي r r r درجة.

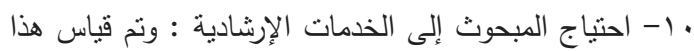

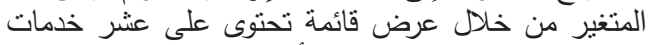
ارشادية وطلب من كل مبحوث أن أن يحدد احتياجه لكت لكل خدمة

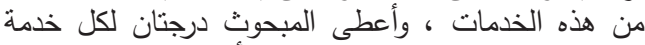

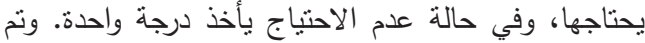

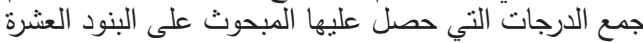

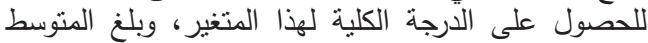
الحسابي 17,7 الح درجة.

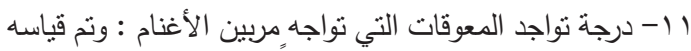

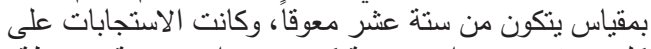

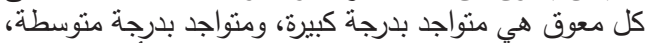

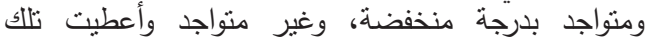

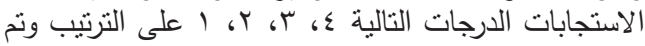

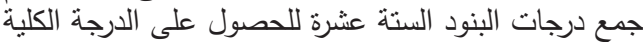

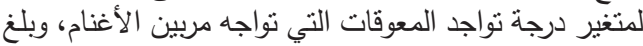

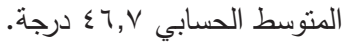

ثانياً : قياس المتغير التابع :

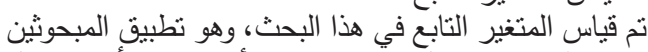

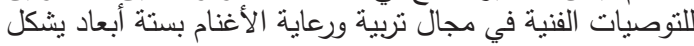

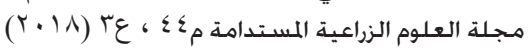




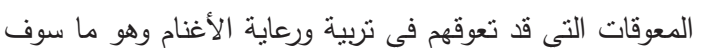

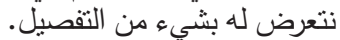

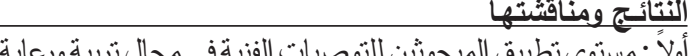
الأغنام.

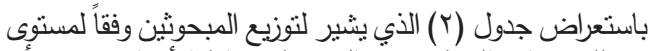

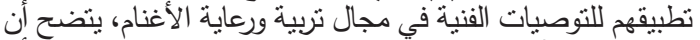

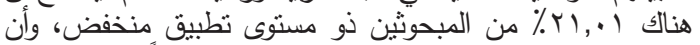

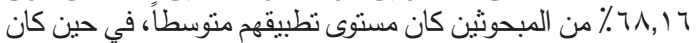

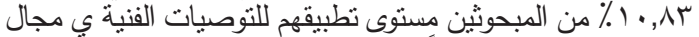
تربية ورعاية الأغنام مرتفعاً.
والحيازة الحيوانية، وأن نحو خمسي المبحوثين كان اتجاههم أما

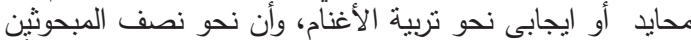

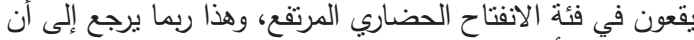

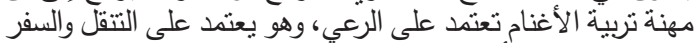

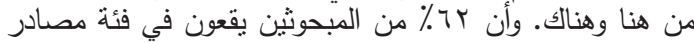

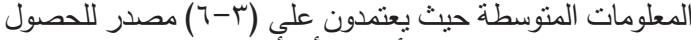

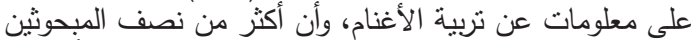
كان درجة احتباجهم للخدمات الإرشادية مرتفعة حيث الإن وجد أن أن نحو

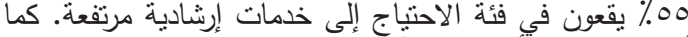

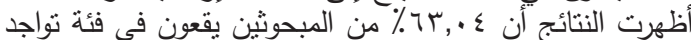
المعوقات المرتفعة وهذا يعني أن مربين الأغنام يواجهون كثير من فئن فراجن

جدول 1. توزيع المبحوثين وفقاً لخصائصهم الشخصية

\begin{tabular}{|c|c|c|c|c|c|}
\hline$\%$ & 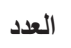 & الخصـائص & $\%$ & 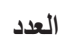 & الخصـائص \\
\hline & & V- الاتجاه نحو تربية الأغنام : & & & 1- السن : \\
\hline 11,09 & 17 & سلبى ( (- 9) درجة & $r v, \uparrow \uparrow$ & or & سنة \\
\hline$\varepsilon \varepsilon, Y)$ & 7 & محايد (·• (1 ـ 1) درجة & $0 ., \ldots$ & 79 & ) \\
\hline \multirow[t]{2}{*}{$\varepsilon \varepsilon, r$. } & 71 & ايجابى(10 - 1 1 ) درجة & IT, & iv & 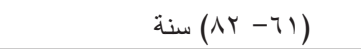 \\
\hline & & ^- الانفتاح الحضاري : & & & r- عدد سنوات التعليم : \\
\hline$\wedge, \vee$. & ir & منخفض (0- ^) درجة & $V 7, .9$ & 1.0 & ) - (0) سنة \\
\hline$\varepsilon \cdot, 01$ & 07 & متوسط (9- 1 (1) درجة & $0, \cdot v$ & v & (1) - 11) سنة \\
\hline \multirow[t]{2}{*}{$0 ., V Y$} & v. & مرتفع (ז - 10 1) درجة & $\curlywedge \wedge, \wedge \varepsilon$ & r & 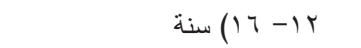 \\
\hline & & 9- مصادر المعلومات في مجال تربية الاغنام: & & & r- الخبرة في مجال تربية الاغنام : \\
\hline$r r, q)$ & זr & قليلة (صفر - r) مصدر & or, 9 . & vr & منخفض (r- 1 (1) سنة \\
\hline Tt, & 人т & منوسطة (r- ؟) مصدر & $r r, q)$ & r & متوسط (19 - مبr) سنة \\
\hline \multirow[t]{2}{*}{ Ir,vV } & 19 & كثيرة (v- (9) مصدر & $r r, 19$ & re & مرتفع (דr- r r) سنة \\
\hline & & • 1-الاحتياج إلى خدمات إرشادية: & & & ع- المساحة المزروعة بالأعلاف: \\
\hline Ir,VV & 19 & منخفض (·• (- سا) درجة & $91, r$. & Kr & صغيرة (صفر - .9 1 ) قيراط \\
\hline T1,17 & s & منوسط (ع ا- ד1) درجة & $\varepsilon$, ro $_{0}$ & 7 & منوسطة (191- וیr) قيراط \\
\hline \multirow[t]{2}{*}{$00, \cdot v$} & $\mathrm{VY}$ & مرتفع (VIV- • r) درجة & $\varepsilon, r_{0}$ & 7 & 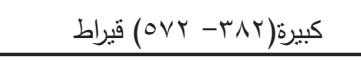 \\
\hline & & 11 1 -ـرجة تواجد المعوقات التى تواجه مربي الاغنام: & & & ه- حجم حيازة الأغنام: \\
\hline$v, 9 v$ & 11 & منخفضة (7 ו- צY) درجة & $\wedge 9,11$ & אזו & كنخفض (•r- r| (1) رأس \\
\hline$r \wedge, 99$ & $\varepsilon$. & متوسطة (YV- & $0, \wedge$ & $\wedge$ & متوسط (ع | (1-7 • r) رأس \\
\hline \multirow[t]{5}{*}{$\pi$} & AV & 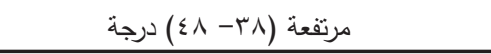 & $0, \cdot v$ & v & 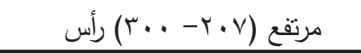 \\
\hline & & & & & ب- حجم الحيازة الحيوانية: \\
\hline & & & $94, \cdot r$ & ITV & منخفض (صفر - 10) وحدة \\
\hline & & & $0, \cdot v$ & v & متوسط (Y Y Y + ( ) وحدة \\
\hline & & & $r, q$. & $\varepsilon$ & مرتفع (ץ. ا- ــ 1) وحدة \\
\hline
\end{tabular}

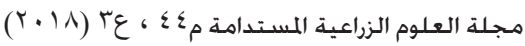


أ- مستوى تطبيق المبحوثين للتوصيات الفنية الخاصة بتجهيز مساكن

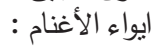

باستعراض جدول (ب) الذي يشير إلى توزيع المبحوثين وفقاً

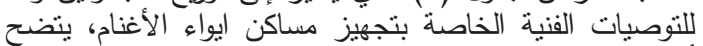

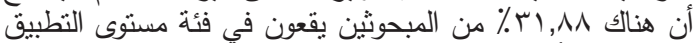

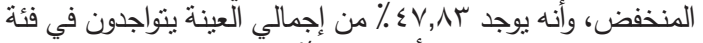

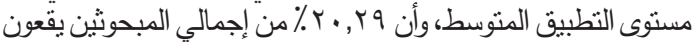
في فئة مستوى النطبيق المرتفع.

ويتضح من بيانات الجدول أن نحو ثلث المبحوثين كان مستوي إنداء

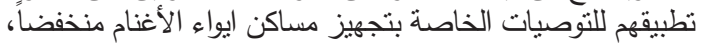

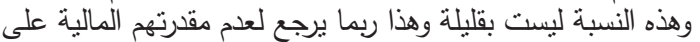

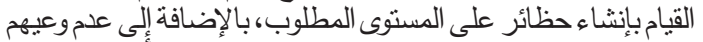

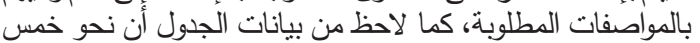

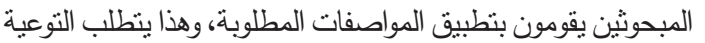
واعطاء الإرشادات الفنية لهؤلاء المربين بهذه التوات التوصيات والمتابعة

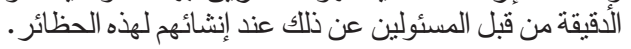

وعند استعراض نطبيق المبحوثين لكل توصية من التوصيات

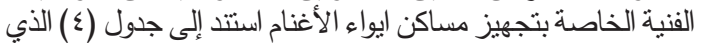

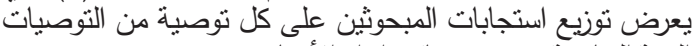
الفنبة الخاصنة بتجهيز مساكن ايواء الأغنام.
يتضح من الجدول أن ما يزبد عن ثلثي المبحوثين بقعون في فئة

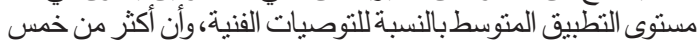

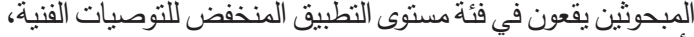

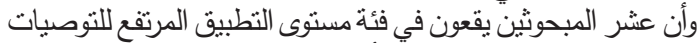

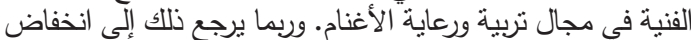

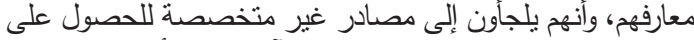

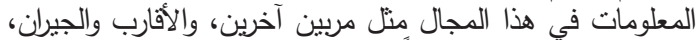

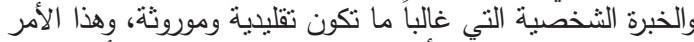

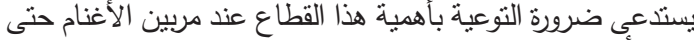

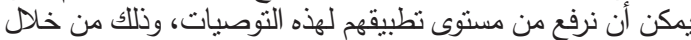
التوعية والمتابعة المستمرة من خلال عقد الندون لندوات والدورات التدريبية

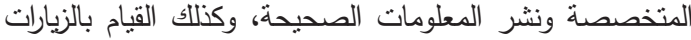

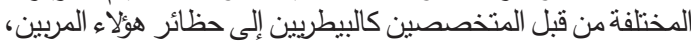
وحثهم على الاتصال المستمر بهولّاء المتخصصنين.

مسنتى تطبيق المبحوثين للتوصيات الفنية في مجال تربية ورعاية الأغنام بمنطقة البحث : المبحثن

والخاصة بالمجالات الستة المدروسة وهي : النتوصيات الفنية

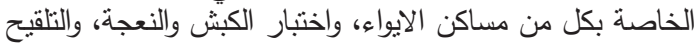

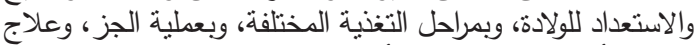
بعض الأمراض الثائعة في الأغنام.

\begin{tabular}{|c|c|c|}
\hline$\%$ & 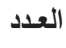 & مستـوى التطبيـق \\
\hline$r 1, \cdot 1$ & rq & 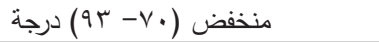 \\
\hline $7 \Lambda, 17$ & $9 \leq$ & متوسط (؟ 9- 111 (1) درجة \\
\hline 1., הr & 10 & 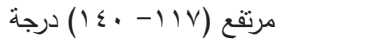 \\
\hline $1 \ldots$ & 1ro & المجمـوع \\
\hline
\end{tabular}

جدول r. توزيع المبحوثين وفقاً لمستوى تطبيقهم للتوصيات الفنية الخاصة بتجهيز مساكن ايواء الأغنام

\begin{tabular}{|c|c|c|}
\hline$\%$ & العـد & مستـوى التطبيـق \\
\hline 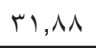 & $\leq \varepsilon$ & منخفض (v- q) درجة \\
\hline$\varepsilon V, \wedge r$ & 77 & متوسط (· ( - Y |) درجة \\
\hline$r \cdot, r q$ & rA & مرتفع (rا- 1 1) درجة \\
\hline $1 \ldots$ & $1 \mu_{1}$ & الدجــوع \\
\hline
\end{tabular}

\begin{tabular}{|c|c|c|c|c|}
\hline \multicolumn{2}{|c|}{ ل الا يطبق } & \multicolumn{2}{|c|}{ يطبـق } & \multirow{2}{*}{ التوصيــات } \\
\hline$\%$ & العدد & $\%$ & العدد & \\
\hline $1 \wedge, \wedge$ & ז & $\lambda ו, r$. & $11 \%$ & 1- اختيار المكان جيد التهوية عند بناء الحظائر . \\
\hline$\leqslant 1, r$. & or & $0 \wedge, \vee \cdot$ & $\wedge$ & r- عند إنثاء الحظائر براعى أن لا يقل ارتفاعها عن זّم . \\
\hline$\varepsilon r, 0$. & 7. & 07,0 . & v^ & r- بناء الحظائر في اتجاه معاكس للريح للوقاية من العواصف والرمال . \\
\hline $01, \varepsilon$. & VI & $\varepsilon \wedge, \uparrow$. & TV & ع- بناء الحظائر في الأماكن التي لا برتقع بها منسوب الماء للحد من انتشار الطفيليات. \\
\hline $09, \varepsilon$. & Ar & $\varepsilon \cdot, 7$. & 07 & 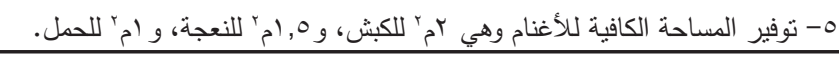 \\
\hline r & $\Lambda V$ & rV & 01 & 1- تخصيص مكان للحملان المولودة والأغنام المريضة. \\
\hline VT,, . & $1 \cdot 1$ & $r \uparrow, \wedge$ & re & V- زراعة أنشار بجوار الحظيرة لاستراحة الأغنام تحتها وقت ارتفاع الحرارة. \\
\hline
\end{tabular}




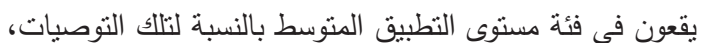

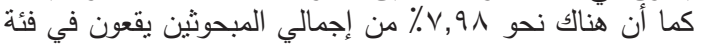
مستوى النطبيق المرتفع بالنسبة للتوصيات الفنية الخاصة بالتلتيح والاستعداد للولادة.

ويتضح من بيانات الجدول أن منوال توزيع المبحوثين يتمركز

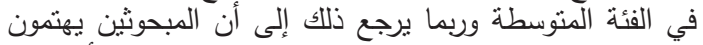

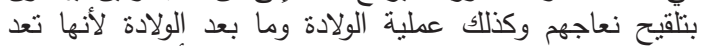

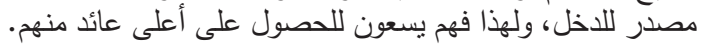

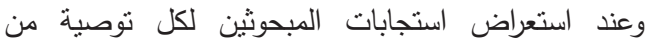

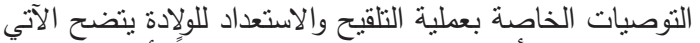

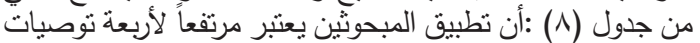

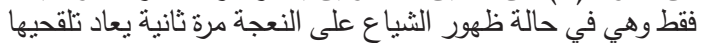

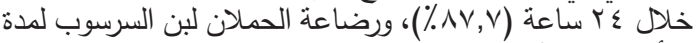

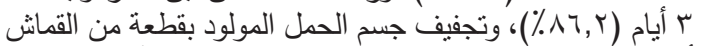

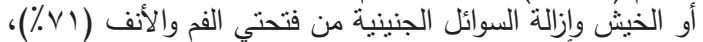

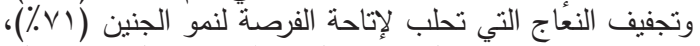

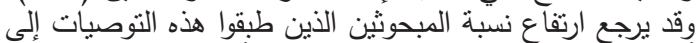
أنها غير مكلفة للمربين، وسهولة نطبيقة الطيا وأنها غير معقدة.

في حين يعتبر تطبيق المبحوثين منوسطاً لستة نوصيات

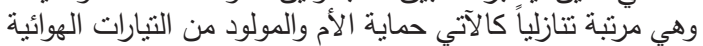

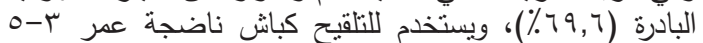

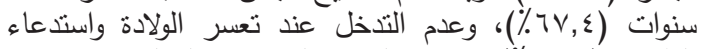
الطبيب (1, • ؟\%)، وحقن النعاج الضعيفة بالسيلينوم وفيتامين

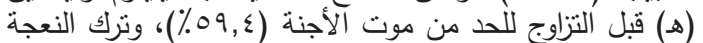

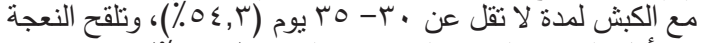

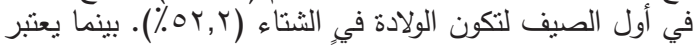

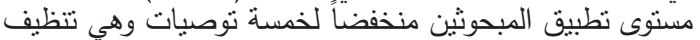

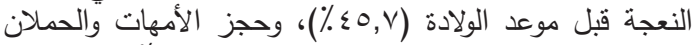

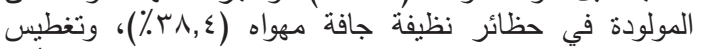

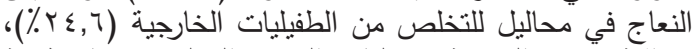

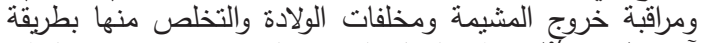

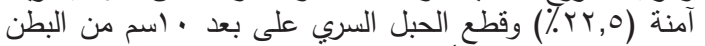

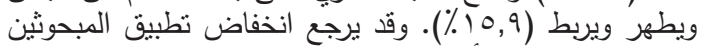
لهذه التوصيات إلى أن هذه النوصيات تحتاج إنى إلى جهر ومكلفة.

د- مستوى تطبيق المبحوثين للتوصيات الفنبة الخاصة بتغذية

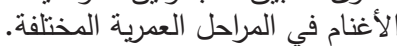

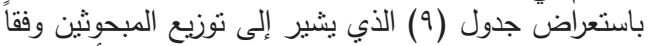

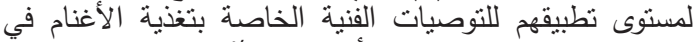

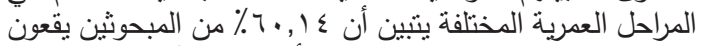

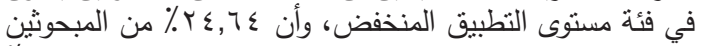

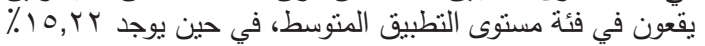
من المبحوثين في فئة مستوى النطبيق المرتنقع

ويتضح من الجدول أن منوال توزيع المبحوثين يتمركز حول الفئة

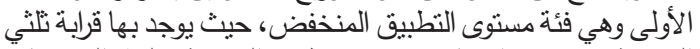

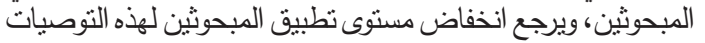

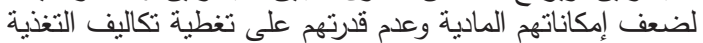
بالعلائق المركزة وصغر حجم حيازتهم المزروعة بالأعلاف الخضراء.

وباستعراض استجابات المبحوثين لكل توصية من التوصيات

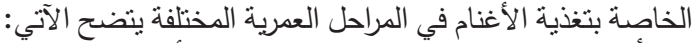

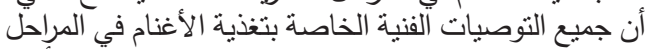

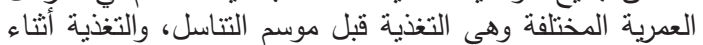

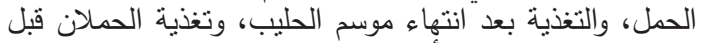

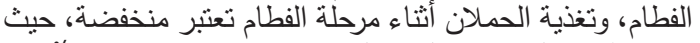

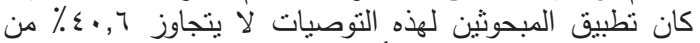

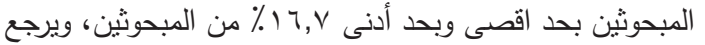

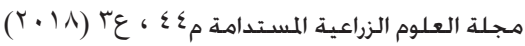

أوضحت النتائج بجدول (ع) أن تطبيث المبحوثين للتوصبات

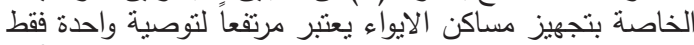

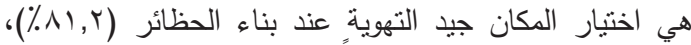

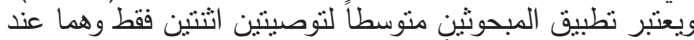

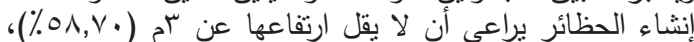

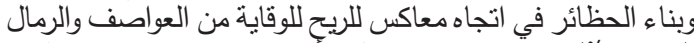

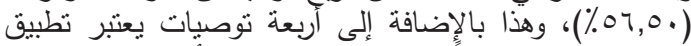

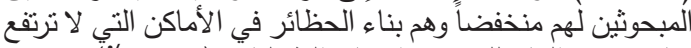

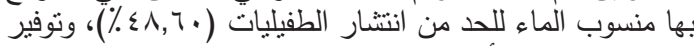

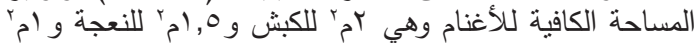

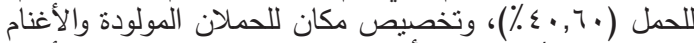

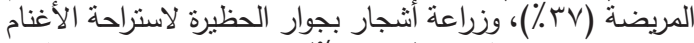

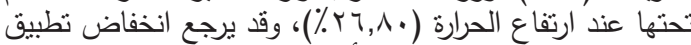

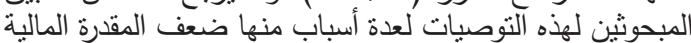

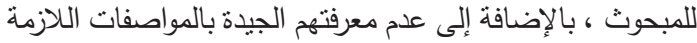

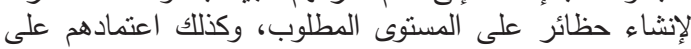

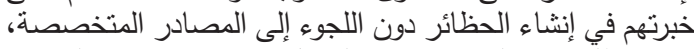

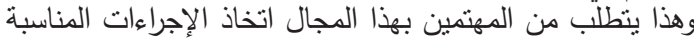

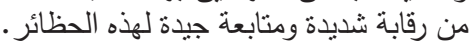

ب- مستوى نطبيق المبحوثين للتوصيات الفنية الخاصة باختيار

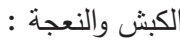

باستعراض جدول (0) الذي يشير إلى توزيع المبحوثين وفقاً

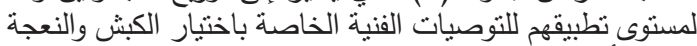

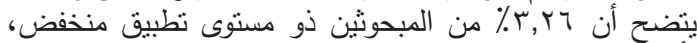

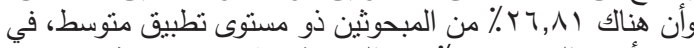

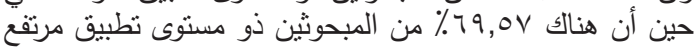
للتوصيات الفنية الخاصة باختيار الكبش والنعجة.

ويتضح من الجدول السابق أن أكثر من ثلثي عينة المبحوثين

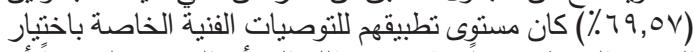

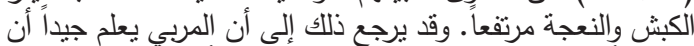

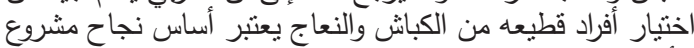

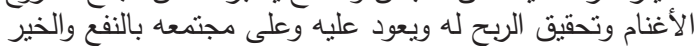

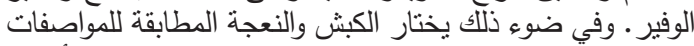

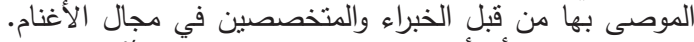

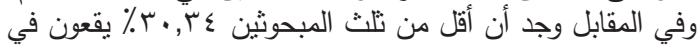

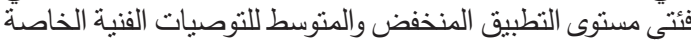

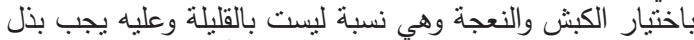

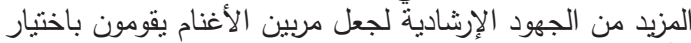

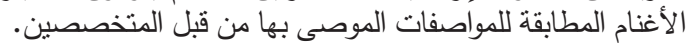

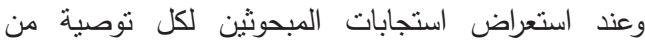

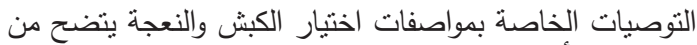

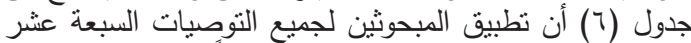

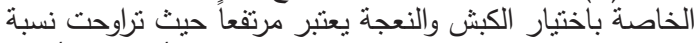

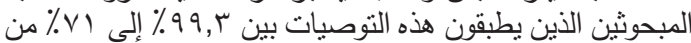

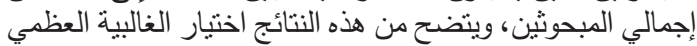

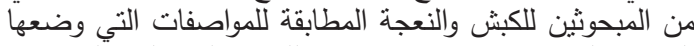

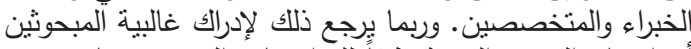

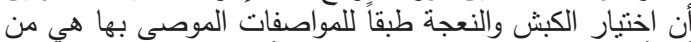

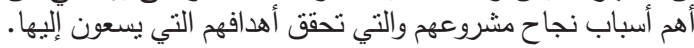
ج- مستوى تطبيق المبحوثين للتوصيات الفنية الخاصة بالتلقيح والاستعداد للولادة:

باستعراض جدول لالعادة (V) الذي يشير إلى توزيع المبحوثين وفقاً

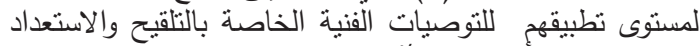

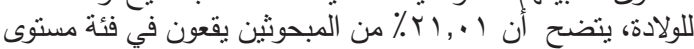

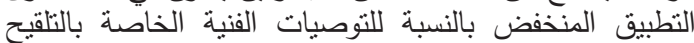

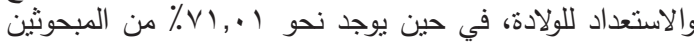


جدول هـ توزيع المبحوثين وفقاً لمستوى تطبيقهم للتوصيات الفنية الخاصة باختيار الكبش والنعجة

\begin{tabular}{|c|c|c|}
\hline$\%$ & العدد العد & مستـوى التطبيـق \\
\hline r,Tr & 0 & منخفض (V- \\
\hline Y૫,A & rv & متوسط (r - 1 ( درجة \\
\hline $79,0 \mathrm{~V}$ & 97 & مرتفع (q ז- ع ז) درجة \\
\hline $1 \ldots$ & אז & المجــوع \\
\hline
\end{tabular}

جدول 4.

\begin{tabular}{|c|c|c|c|c|}
\hline \multicolumn{4}{|c|}{ التطبيــق } & \multirow{3}{*}{ التوصيـــات } \\
\hline \multicolumn{2}{|c|}{ لا يطبق ابق } & \multicolumn{2}{|c|}{ 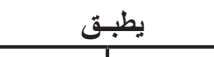 } & \\
\hline$\%$ & 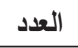 & $\%$ & 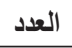 & \\
\hline$\cdot, \mathrm{V}$ & 1 & $99, r$ & irv & 1- أن يكون الكبش والنعجة شديد الحيوية (حركة وقوة ونشاط) . \\
\hline$\cdot, \mathrm{V}$ & 1 & $99, r$ & irt & r- أن تكون القوائم الأمامية والخلفية للكبش والنعجة سليمة وقوية . \\
\hline$\cdot, \mathrm{V}$ & 1 & $99, r$ & irv & r- أن يكون ضرع النعجة سليم وحجمه مناسب وإسفنجي وغير مدلى . \\
\hline $1, \varepsilon$ & r & $9 \wedge, 7$ & 144 & ع- أن يكون الكبش والنعجة من سلالة عالية الانتاج . \\
\hline $1, \varepsilon$ & r & $9 \wedge, 7$ & 147 & 0- أن نكون حلمات النعجة سليمة خالية من النتققات وقنواتها مفتوحة . \\
\hline$r, q$ & $\varepsilon$ & $9 \vee, 1$ & $1 \pi \varepsilon$ & 7- أن يكون الكبش متوسط الحجم وسليم الخصبيتين . \\
\hline$\varepsilon, r$ & 1 & $90, \mathrm{~V}$ & ITr & V - أن يكون الكبش والنعجة خاليان من العيوب التناسلية. \\
\hline 0,1 & $\wedge$ & $9 \varepsilon, r$ & $1 \%$ & ^- أن يكون الكبش والنعجة ـُقبلين على تتاول الأعلاف المركزة والخضراء . \\
\hline 7,0 & 9 & 94,0 & 149 & 9- أن تكون أسنان الكبش والنعجة سليمة وقوية . \\
\hline $\mathrm{V}, \mathrm{r}$ & $1 \cdot$ & $9 r, \Lambda$ & irk & • 1- أن تكون سلسلة ظهر الكبش والنعجة مغطاة باللحم والظهر غير مقوس . \\
\hline$\Lambda, \vee$ & ir & 91,0 & $1 \times 4$ & 11 - أن يكون الكبش والنعجة خاليان من الإصابة بالأمراض والطفيليات . \\
\hline$\Lambda, \mathrm{V}$ & ir & $91, r$ & $1 \times 4$ & r r - أن يكون الكبش والنعجة ذات عيون براقة وسليمة وخالية من الإفرازات . \\
\hline $1 \leqslant, 0$ & r. & 10,0 & 111 & r ا - أن تكون معالم الذكورة واضحة في الكبش (غليظ القرون وكبير الرأس وقوى الفكين). \\
\hline 10,9 & rt & $\wedge \varepsilon, 1$ & 117 & ـ ا - أن يكون صوف الكبش والنعجة لامع وغزير وناعم ولا ينقصف بمجرد شدة . \\
\hline $17, \mathrm{~V}$ & rt & $\Lambda r, r v$ & 110 & 1 - أن تكون النعجة هادئة الطباع وغير سمينة وفي عمر مناسب للتربية. \\
\hline$r \cdot r$ & rA & $\vee १, \vee$ & 11. & 17 - أن تكون أرجل الكبش والنعجة غير منباعدة أو مقوسة. \\
\hline r৭, ६. & $\varepsilon$. & $v_{1}$ & 91 & VI أن ألنكون الكبش والنعجة خاليان من أي إفرازات أو ارتثاحات أو التهابات في الأنف والفم \\
\hline
\end{tabular}

جدول v. توزيع المبحوثين وفقاً لمستوى تطبيقهم للتوصيات الفنية الخاصة بالتلقيح والاستعداد للولادة

\begin{tabular}{|c|c|c|}
\hline$\%$ & العدد & مستـوى التطبيـق \\
\hline$r 1, \cdot 1$ & rq & منخفض (0 1- 9 1) درجة \\
\hline$v_{1}, .1$ & $9 \wedge$ & متوسط (•r - ه ץ) درجة \\
\hline$\vee, 9 \wedge$ & 11 & 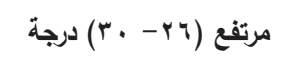 \\
\hline $1 \ldots$ & Irk & المجمـوع \\
\hline
\end{tabular}


جدول ^. توزيع استجابات المبحوثين وفقا لتطبيقهم لكل توصية من التوصيات الفنية الخاصة بعملية التلقيح والاستعداد للولادة مرتبة تنازلياً

\begin{tabular}{|c|c|c|c|c|}
\hline \multicolumn{4}{|c|}{ التطبيــق } & \multirow{3}{*}{ التوصيـــات } \\
\hline \multicolumn{2}{|c|}{ ل الا يطبق } & \multicolumn{2}{|c|}{ 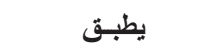 } & \\
\hline$\%$ & العدد & $\%$ & العدد & \\
\hline ir,r & iv & $\wedge \vee, \vee$ & $|r|$ & 1- في حالة ظهور الثياع على النعجة مرة ثانية يعاد تلقيحها خلال ع ب ساعة. \\
\hline $1 r, \Lambda$ & 19 & $\wedge 4, r$ & 119 & ץ- رضاعة الحملان لبن سرسوب لمدة ؟ أيام. \\
\hline rq & $\varepsilon$. & (1) & $9 \wedge$ & r- تجفيف الحمل المولود بقطعة من القماش أو الخيش وإزالة السوائل الجنينية من فتحتي الفم \\
\hline rq & $\varepsilon$. & $v_{1}$ & $9 \wedge$ & ع - تجفيف النعاج التي تحلب لإتاحة الفرصة لنمو الجنين. \\
\hline r.,, & $\leq r$ & 79,7 & 97 & ه- حماية الأم والمولود من التيارات الهوائية الباردة . \\
\hline r T & 纟o & $T \vee, \varepsilon$ & 94 & 1- يستخدم للتلقيح كباش ناضجة عمر ץ- 0 سنوات . \\
\hline rq, & 00 & $7 \cdot, 1$ & Ar & V- عدم التذخل عند تعسر الولادة واستدعاء الطبيب . \\
\hline$\varepsilon \cdot, \uparrow$ & 07 & $09, \varepsilon$ & Ar & ^- حقن النعاج الضعيفة بالسيلينوم وفيتامين (ه) قبل التزاوج للحد من موت الأجنة. \\
\hline$\leqslant 0, v$ & r & $0 \leqslant, r$ & vo & 9- نترك النعجة مع الكبش لمدة لا نقل عن ·. ب- مب يوم. \\
\hline$\varepsilon \vee, \Lambda$ & 77 & Or, r & vr & • 1- تلقح النعجة في أول الصيف لتكون الولادة في الثتاء. \\
\hline $0 \leqslant, r$ & vo & $\leq 0, v$ & rit & 11- نتظيف النعجة قبل موعد الولادة. \\
\hline 7,7 & 10 & 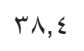 & or & r ا- حجز الأمهات والحملان المولودة في حظائر نظيفة جافة مهواه . \\
\hline$\vee \circ, \varepsilon$ & $1 \cdot \varepsilon$ & $r \varepsilon, T$ & $r \varepsilon$ & r ا - تغطيس النعاج في محاليل للتخلص من الطفيليات الخارجية. \\
\hline$V Y, 0$ & $1 \cdot v$ & 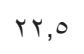 & $\mu$ & ـ ا - مراقبة خروج المشيمة ومخلفات الولادة والتخلص منها بطريقة آمنة. \\
\hline$\wedge \varepsilon, 1$ & 117 & 10,9 & rt & ه ا - قطع الحبل السري على بعد اسم من البطن ويطهر ويربط . \\
\hline
\end{tabular}

جدول 9. توزيع المبحوثين وفقاً لمستوى تطبيقهم للتوصيات الفنية الخاصة بتغنية الأغنام في المراحل العمرية المختلفة

\begin{tabular}{|c|c|c|}
\hline$\%$ & العدد العد & مستـوى التطبيـق \\
\hline $7 \cdot, 1 \leq$ & Ar & منخفض (10- 9 1) درجة \\
\hline$T \leqslant, T \leqslant$ & $\Gamma \varepsilon$ & متوسط (•r- • • درجة \\
\hline $10, r Y$ & r) & مرتفع (ךץ- • +ץ) درجة \\
\hline $1 \ldots$ & $1 \pi \lambda$ & المجمـوع \\
\hline
\end{tabular}

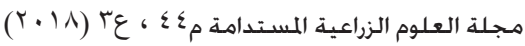


جدول . ا. توزيع استجابات المبحوثين وفقا لتطبيقهم لكل توصية من التوصيات الفنبة الخاصة بتظذية الأغنام في المراحل العمرية المختلفة مرتبة تنازلياً

\begin{tabular}{|c|c|c|c|c|}
\hline \multicolumn{4}{|c|}{ 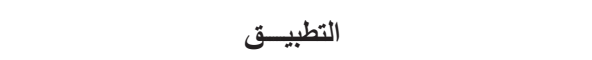 } & \multirow{3}{*}{ التوصيــات } \\
\hline \multicolumn{2}{|c|}{ لا يطبق } & \multicolumn{2}{|c|}{ 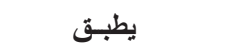 } & \\
\hline$\%$ & العدد & $\%$ & العدد & \\
\hline $09, \varepsilon$ & At & $\varepsilon \cdot, \uparrow$ & 09 & أ- التخذية قبل موسم التناسل : 1 أنعطى النعجة أو الكبش برسيم أخضر بحيث لا يزيد عن ه\% من الاحتياجات . \\
\hline 70,9 & 9) & $r \varepsilon, 1$ & $\varepsilon v$ & r- تزود كمية العليقة المركزة بمقدار هץ-· بـ ويفضل أن تكون من الثعير أو الذرة. \\
\hline$T T, Y$ & ar & rr, tr & $\varepsilon 1$ & r- إضافة فيتامين (أ) والفوسفور لزيادة النشاط الجنسي. \\
\hline & & & & 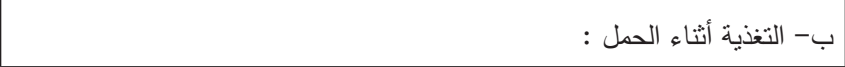 \\
\hline ฬ, 1 & $9 \varepsilon$ & r, १ & $\varepsilon \varepsilon$ & ع - في التنالث تصعبر الؤلادة. \\
\hline 79,7 & 94 & $r \cdot, \varepsilon$ & $\varepsilon r$ & ه- في ا(المرحلة الأخيرة من الحمة الجنين .تقم فيتامين (أ) أو علفة خضراء كمصدر لفيتامين \\
\hline (1) & $9 \wedge$ & rq & $\varepsilon$. & צ- في الثلث لتسهيل الألولادة. الحمل يفضل تغذية النعاج على الثعير والمولاس بكمية \\
\hline Vr, r & 1.1 & $r \uparrow, \Lambda$ & $r v$ & v- في الثنثلث الأخير من الحمل يتم زيادة كمية العلائق المركزة وتخفيف العلائق \\
\hline$\Lambda_{\cdot}, \varepsilon$ & 111 & 19,7 & rV & 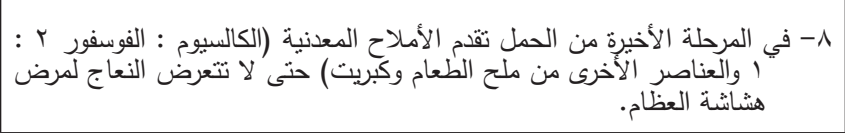 \\
\hline & & & & ج- التظذية بعد انتهاء موسم الحليب : \\
\hline$\wedge 1,9$ & $11 \pi$ & $1 \Lambda, 1$ & ro & 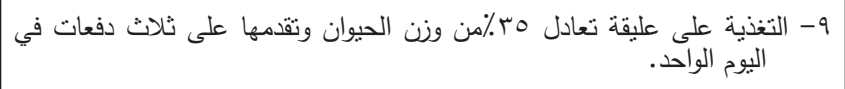 \\
\hline Ar,r & 110 & $17, \mathrm{~V}$ & r & ـ ـ - تقدم عليقة تلثيها عليقة خشنة والتلث الأخر أعلاف مركزة. \\
\hline & & & & د- تغذية الحملان قبل الفطام : \\
\hline 71,7 & 10 & $\lceil\Lambda, \varepsilon$ & or & 11 - تغذية الحملان على أعلاف مستساغة وذو قيمة عالية وتقدم على دفعات لا تزيد \\
\hline$v v, 0$ & $1 . \mathrm{V}$ & $r r, O$ & $r_{1}$ & 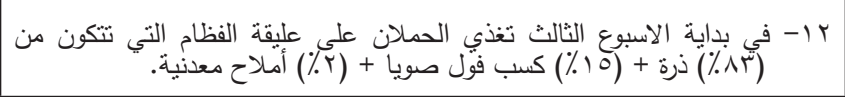 \\
\hline & & & & هـ- تغذية الحملان اثناء مرحلة الفطام : \\
\hline 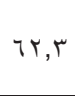 & NT & $r v, v$ & or & r ا - تغذية الحملالن شتاء على r كجم برسيم + ربع كجم مركزات (شعير - ذرة- قصح- \\
\hline$\pi r, \Lambda$ & м & m, & $\circ$. & ع ا - تغذية الحملان صيفاً على ا كجم دريس+ ربع كجم مركزات. \\
\hline$v_{1}$ & 91 & rq & $\varepsilon$. & 10- التكريج عند تغيير عليقة بأخرى لتجنب الاضطرابات الهضمية. \\
\hline
\end{tabular}


لإجرائها أو خبرة عالية، وفي بعض الأحبان قد تكون مربحة

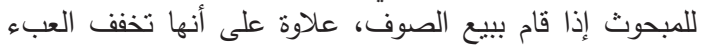
الحراري للأغنام وتفتح شهية الحيوان، وكذللك تساعد في مقاومة الألة الأمراض الجلدية والطفيليات للأغنام المصابة.

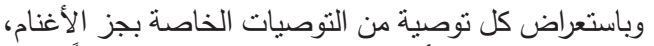

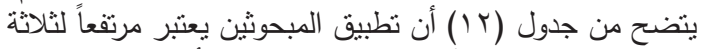

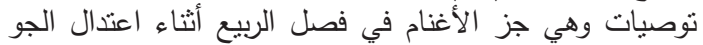

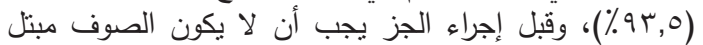

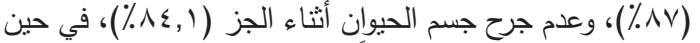

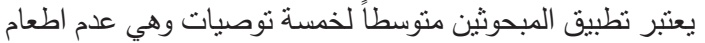

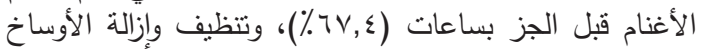

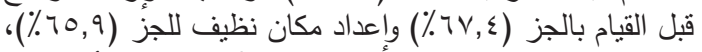

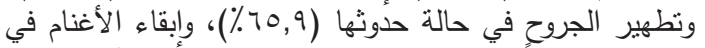

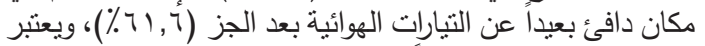

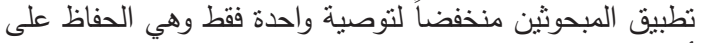

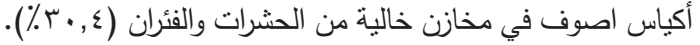

ويتضح مما سبق أن 90,9\%٪أكثر من المبحوثين يقومون

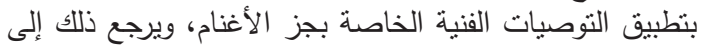

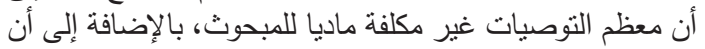

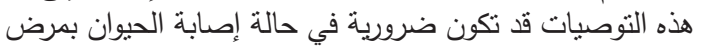

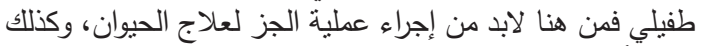

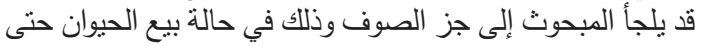

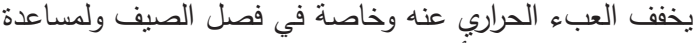

الحيوان ودفعه إلى الأكل وخاصة عند الحئ القيام بتسمين الحيوان.

و - مستوى نطبيق المبحوثين للتوصيات الفنية الخاصة بعلاج

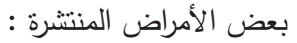

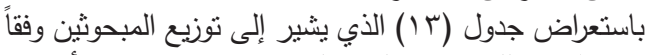

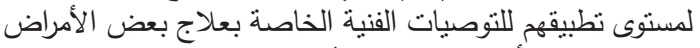

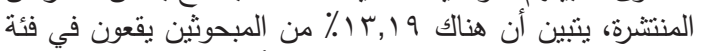

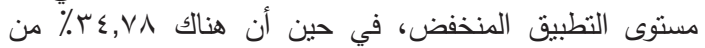

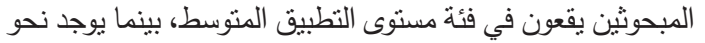

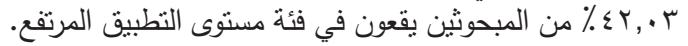

نستتتج مما سبق أن منوال نوزيع المبحوثين يتمركز حول الفئة

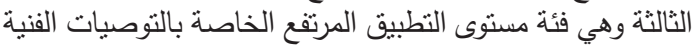

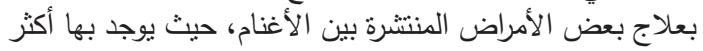

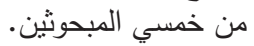

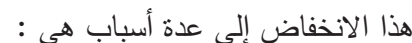

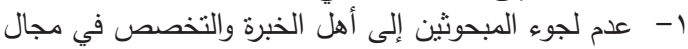
التغذية.

r- عدم وجود أخصائي بيطري أو أخصائي تغذية يقوم بنوعيتهم بما هو مطلوب في مراحل التغذية المختلفة والمقررات المطلوبة.

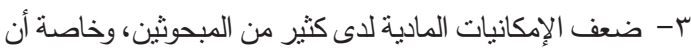
معظم هذه التوصيات مكلفة وتحتاج إلى إمكانيات مادية عالية.

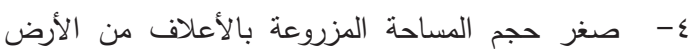

الزراعية كما اتضح من جدول خصائص عينة الدراسة.

0 - اعتماد كثير من المبحوثين على الرعي كأساس لعملية تغذية الأغنام وليس الأعلاف المركزة لأن الرعي غير الرير مكلف.

1- - العشوائية في التغذية بمعنى عدم معرفة المقررات المناسبة لكل مرحلة من مراحل التغذية.

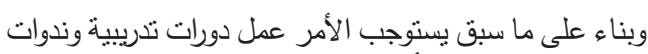

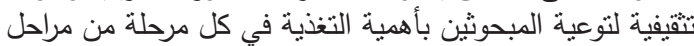

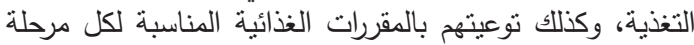
عمرية من خلال عمل برامج عن التغذية تركز على كيفية إعلى إعداد غذاء بالمقررات المطلوبة وغير مكلف وبسيط وسهل النطبيق. هـ - مستوى تطبيق المبحوثين للتوصيات الفنبة الخاصة بجز الأغنام : باستعراض جدول (11) الذي يشير إلى توزيع المبحوثين وفئاً

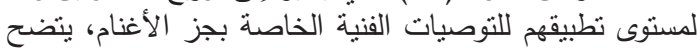

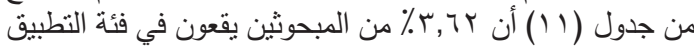

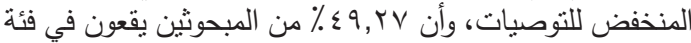

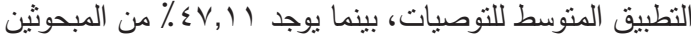
في فئة التطبيق المرتفع.

ويتضح من الجدول أن الغالبية العظمي من المبحوثين بقعون

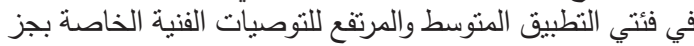

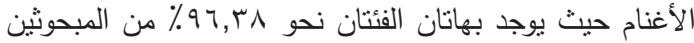

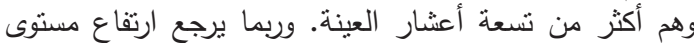

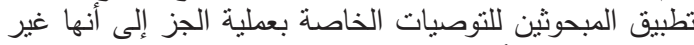

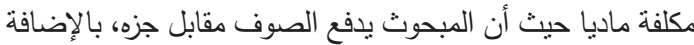

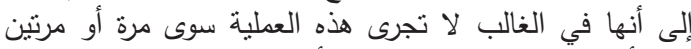
على أقصى تقدير في السنة، كما أنها لا تحتاج إلى وقلى مرة طويل

جدول 11. توزيع المبحوثين وفقاً لمستوى تطبيقهم للتوصيات الفنية الخاصة بجز الأغنام

\begin{tabular}{|c|c|c|}
\hline$\%$ & العدد العد & مستـوى التطبيـق \\
\hline זיד, & 0 & منخفض (9- 1) 1) درجة \\
\hline$\varepsilon १, \uparrow \vee$ & 71 & متوسط (r ا- 0 1) درجة \\
\hline$\leq V, 11$ & 70 & مرتفع (ך ا - ^ 1 ) درجة \\
\hline $1 \ldots$ & $1 \pi 1$ & المجمــوع \\
\hline
\end{tabular}

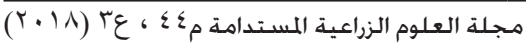


جدول r ا ـ توزيع استجابات المبحوثين وفقا لتطيقهم لكل توصية من التوصيات الفنية الخاصة بجز الأغنام مرتبة تنازلياً

\begin{tabular}{|c|c|c|c|c|}
\hline \multicolumn{4}{|c|}{ التطبيــق } & \multirow[t]{2}{*}{ التوصيــــات } \\
\hline$\%$ & 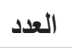 & $\%$ & 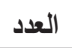 & \\
\hline 7,0 & 9 & 94,0 & 149 & 1- جز الأغنام في فصل الربيع أثثاء اعتدال الجو . \\
\hline 14 & 11 & $\wedge \mathrm{V}$ & ir. & r- قبل اجراء الجز يجب أن لا يكون الصوف مبتل. \\
\hline 10,9 & tr & $\wedge \varepsilon, 1$ & 117 & r- عدم جرح جسم الحيوان أثناء الجز . \\
\hline$r_{T, T}$ & 纟o & $T \vee, \varepsilon$ & 9 & ع - عدم اطعام الأغنام قبل الجز بساعات . \\
\hline$r^{T, T}$ & «o & $T V, \varepsilon$ & 9 & ه- تتظيف وإزالة الأوساخ قبل القيام بالجز . \\
\hline$r \varepsilon, 1$ & $\varepsilon V$ & 70,9 & 91 & 1- إعداد مكان نظيف للجز . \\
\hline$r \varepsilon, 1$ & $\varepsilon V$ & 70,9 & 91 & V- V تطهير الجروح في حالة حدوثها . \\
\hline 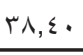 & or & 7,7 & 10 & ^- إبقاء الأغنام في مكان دافئ بعيداً عن التبارات الهوائية بعد الجز . \\
\hline 79,7 . & 97 & $r \cdot, \varepsilon$ & $\varepsilon r$ & 9- الحفاظ على أكياس الصوف في مخازن خالية من الحشرات والفئران. \\
\hline
\end{tabular}

\begin{tabular}{|c|c|c|}
\hline$\%$ & العدد & مستـوى التطبيـق \\
\hline 15,19 & r & منخفض (v- q) درجة \\
\hline$r \varepsilon, \vee \wedge$ & $\varepsilon \wedge$ & متوسط (• 1- 11) درجة \\
\hline$\varepsilon r, \cdot r$ & rı & مرتفع (ץ ו- ع I) درجة \\
\hline $1 \ldots$ & Irk & المجمـوع \\
\hline
\end{tabular}

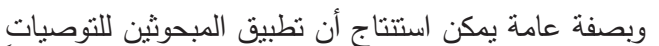

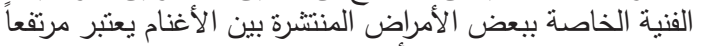

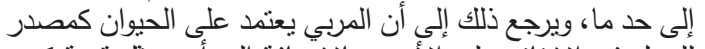

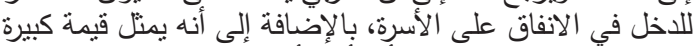

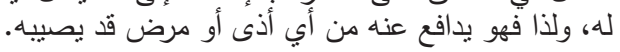
ثانيًا : مصادر المعلومات التي يستقي منها المبحوث معلوماته عن تربية ورعاية الأغنام.

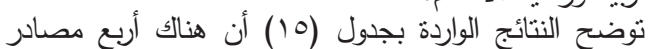

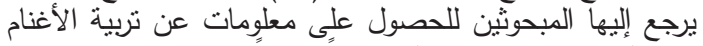

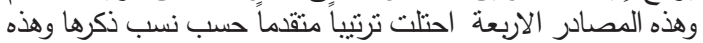

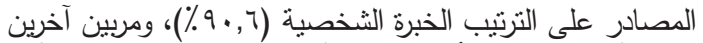

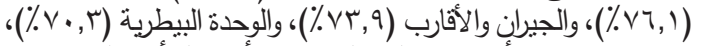

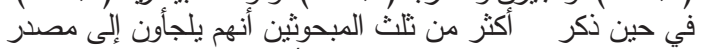

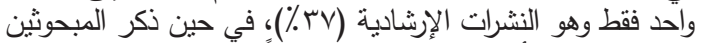

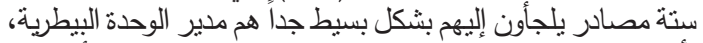

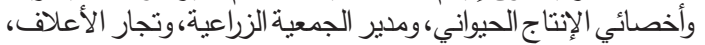

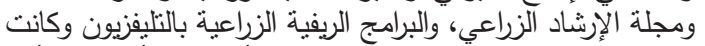

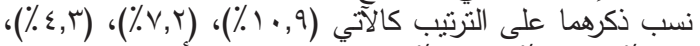

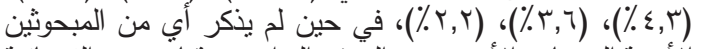

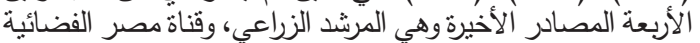
الزراعية، والبرامج الريفية الزرآعية بالإذاعة، ومدير الإنية الإنشاد الزراعي.

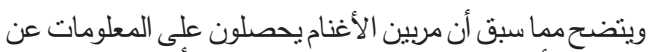

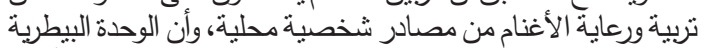
هي المصدر المتخصص الوحيد الذي يسهم في حصول مربين الأغنام

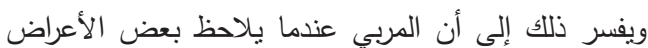

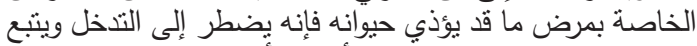

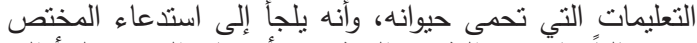

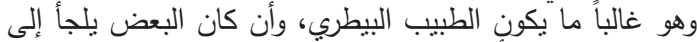

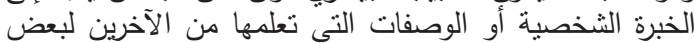

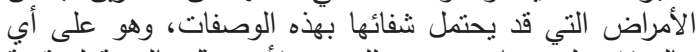

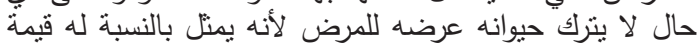
اقتصادية واجتماعية عالية، وأنه مصدر أساسئ لأنس لدخله.

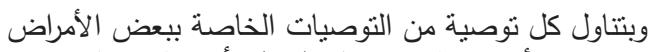

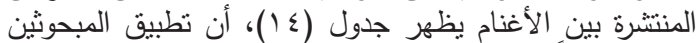

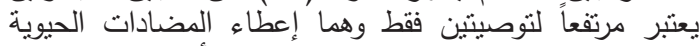

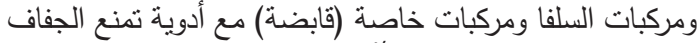

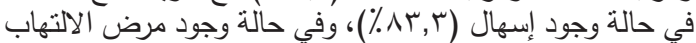

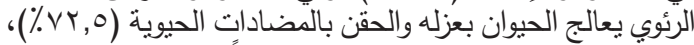

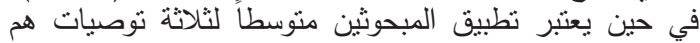

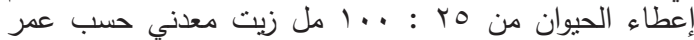

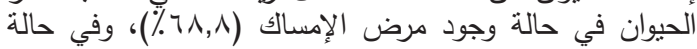

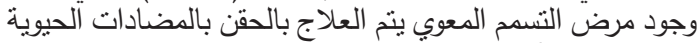

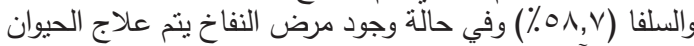

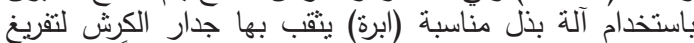

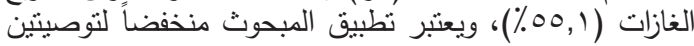

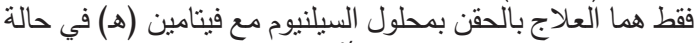

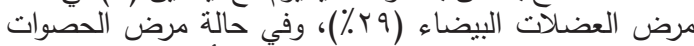

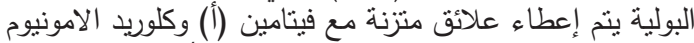

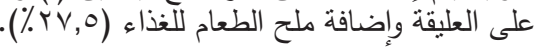

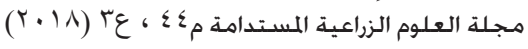




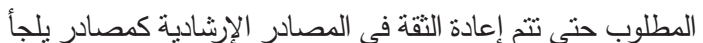

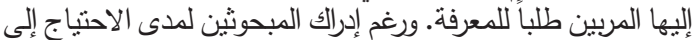

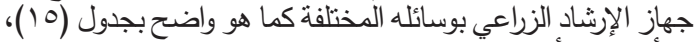

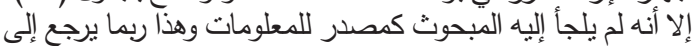

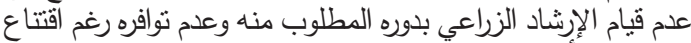
المبحوثين بأهميته في زبادة معارفهم بصفة باعة عامة ومعارفهم عن تربية

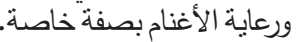

على المعلومات في هذا الثأن، ومن جهة أخرى فإن الإششاد الزراعي والمي

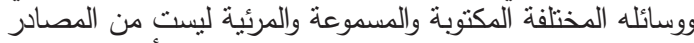

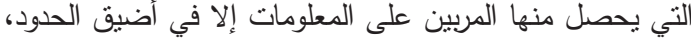

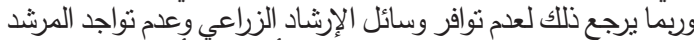

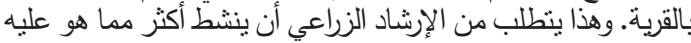

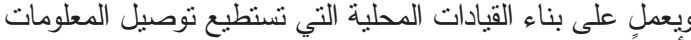

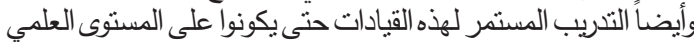

جدول ؛ ا ـ توزيع استجابات المبحوثين وفقا لتطبيقهم لكل توصية من التوصيات الفنبة الخاصة ببعض الأمراض المنتشرة بين الأغنام مرتبة تنازلياً

\begin{tabular}{|c|c|c|c|c|}
\hline \multicolumn{4}{|c|}{ التطبيـق } & \multirow{3}{*}{ التوصيـــات الفتيــة } \\
\hline \multicolumn{2}{|c|}{ ل الا يطبق } & \multicolumn{2}{|c|}{ يطبـق } & \\
\hline$\%$ & العدد & $\%$ & العدد & \\
\hline $17, \mathrm{~V}$ & tr & Ar, & 110 & 1- إعطاء المضادات الحيوية ومركبات السلفا ومركبات خاصة (قابضة) مع أدوية تمنع \\
\hline$r v, 0$ & ${ }^{\prime} \wedge$ & $V Y, O$ & $1 \cdots$ & r- في حالة وجود التهاب رئوب يتم عزل الحيوان والحقن بالمضادات الحيوية. \\
\hline r, r & $\varepsilon r$ & $\top \wedge, \wedge$ & 90 & 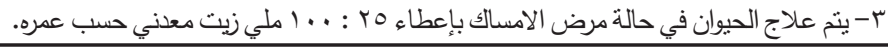 \\
\hline$\varepsilon 1, r$ & ov & $0 \wedge, \mathrm{V}$ & 1) & ـ - يتم العلاج بالحقن بالمضادات الحيوية والسلفا في حالة إصابة الحيوان بمرض التسمم المعوي. \\
\hline$\leq \varepsilon, q$ & $T r$ & 00,1 & Vy & ه- في حالة الإصابة بمرض النفار النفار يتم العلاج باستخدام آلة بذل مناسبة (ابره) يثقب بها \\
\hline VI & 91 & rq & $\varepsilon \cdot$ & 7- يتم الحقن بمحلول السيلينوم + فيتامين (ه) في حالة الإصـابة بمرض العضلات البيضاء. \\
\hline$V Y, 0$ & $1 \ldots$ & $r V, 0$ & ru & 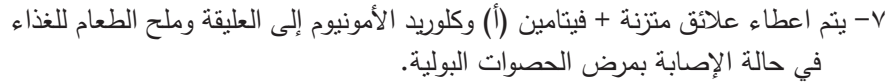 \\
\hline
\end{tabular}

جدول ه 1 ـ ترتيب مصادر مطومات المبحوثين تنازلياً وفقاً لأهميتها

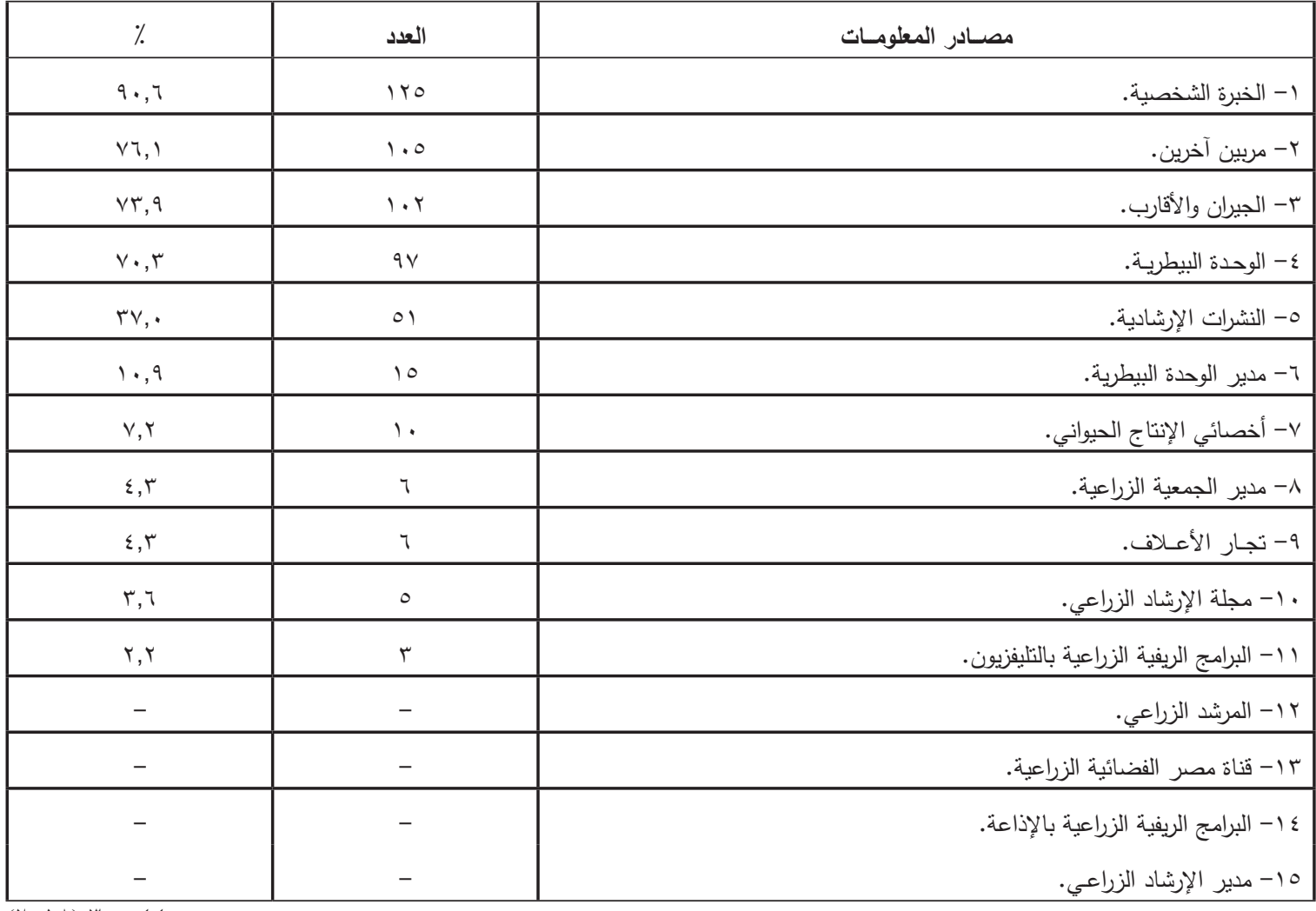




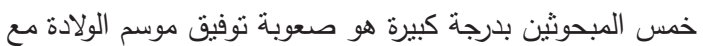

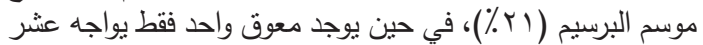

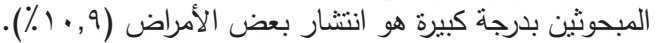
رابعاً : الخدمات الإرشادية التي يحتاجها المبحوثين مربين الأغنام من الإرشاد الزراعي : الإتجات

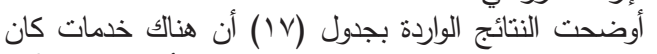

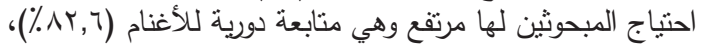

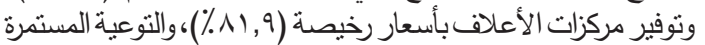

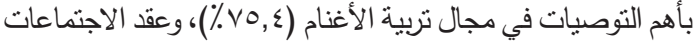

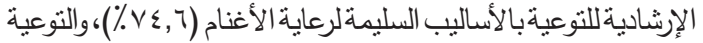
بأساليب التغنية ومعدلاتها للأغنام ( (

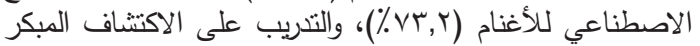

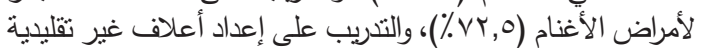

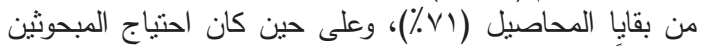

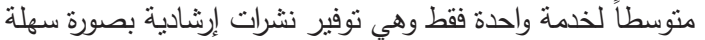

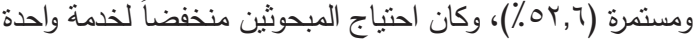

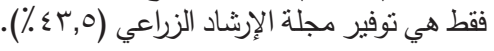

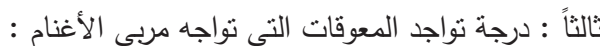

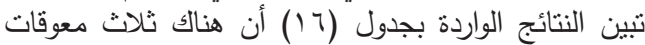

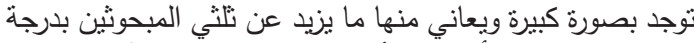

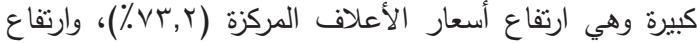

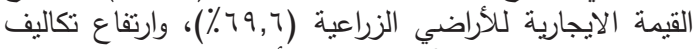

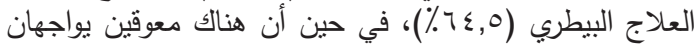

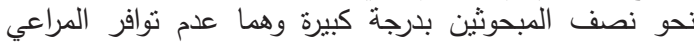

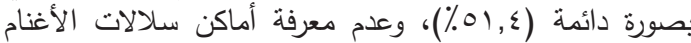

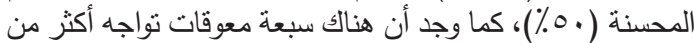

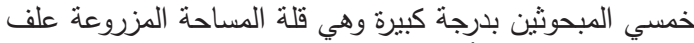

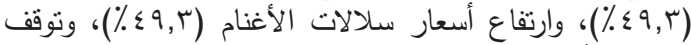

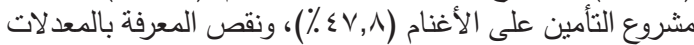

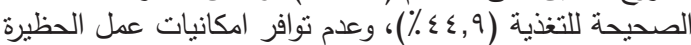

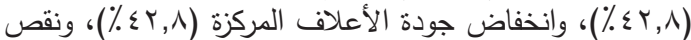

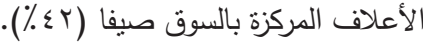

في حين يوجد معوقين يواجها ثلث المبحوثين بدرجة كبيرة وهما

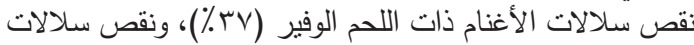

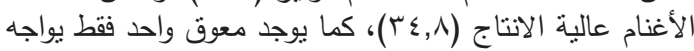

جدول 14 ـ المعوقات التي تواجه مربين الأغنام مرتبة تنازلياً وفقاً لارجة تواجدها

\begin{tabular}{|c|c|c|c|c|c|c|c|c|}
\hline \multicolumn{2}{|c|}{ غير متوفُرة } & \multicolumn{2}{|c|}{ منتوفذة بلرجة } & \multicolumn{2}{|c|}{ متواجدة بلرجة } & \multicolumn{2}{|c|}{ متواجدة بلرجة } & \multirow[t]{3}{*}{ المعوة ــــات } \\
\hline$\%$ & 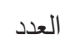 & $\%$ & 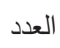 & $\%$ & 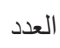 & $\%$ & 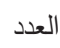 & \\
\hline$\wedge$ & 11 & $\varepsilon, r$ & 7 & $1 \leqslant, 0$ & r. & $V T, r$ & $1 \cdot 1$ & \\
\hline 7,0 & 9 & 0,1 & v & $1 \wedge, \wedge$ & rt & 79,7 & 97 & r- ارتفاع القيمة الايجارية للأراضي الزراعية. \\
\hline 0,1 & $\wedge$ & $V, r$ & 1. & $r$ r,O & r & $T \leqslant, 0$ & 19 & r- ارتفاع تكاليف العلاج البيطري. \\
\hline $17, \mathrm{~V}$ & rt & $9, \varepsilon$ & ir & $r r, 0$ & r & $01, \varepsilon$ & (1) & ـ- عدم توافر المراعي بصورة دائمة. \\
\hline$\lfloor\wedge, \wedge$ & r4 & Ir, r & iv & $\nmid \wedge, \wedge$ & rt & 0. & 79 & 0- عدم معرفة أماكن سلالات الأغنام المحسنة. \\
\hline$r r, q$ & r & 0,1 & $\wedge$ & r) & rq & $\varepsilon 9, r$ & 71 & 1- قلة المساحة المزروعة علف. \\
\hline 19,7 & rr & 7,0 & 9 & $r \varepsilon, T$ & $r \varepsilon$ & $\varepsilon 9, r$ & 71 & لا- ارتفاع أسعار سلالات الأغنام. \\
\hline$r, Y$ & r. & $1 \leqslant, 0$ & r. & 10,9 & rt & $\varepsilon \vee, \wedge$ & 77 & 1- توقف مشروع التأمين على الأغنام. \\
\hline$r r, q$ & זr & $\wedge$ & 11 & $r t, r$ & rt & $\varepsilon \varepsilon, 9$ & Tr & 9- نقص المعرفة بالمعدلات الصحيحة للتغذية. \\
\hline$r 1,9$ & $\varepsilon \varepsilon$ & $1 \cdot, 9$ & 10 & $1 \leqslant, 0$ & r. & $\varepsilon r, \wedge$ & 09 & • 1- عدم توافر إمكانيات عمل الحظيرة. \\
\hline $1 \wedge, \wedge$ & r4 & $1 \cdot, 1$ & $1 \leq$ & $r \wedge, r$ & rq & $\leqslant r, \wedge$ & 09 & 11- انخفاض جودة الأعلاف المركزة. \\
\hline$r \cdot, \varepsilon$ & $\varepsilon r$ & 11,7 & 17 & 10,9 & rr & $\varepsilon r$ & 01 & r 1- نقص الأعلاف المركزة بالسوق صيفا. \\
\hline$r, O$ & m & $1 \leqslant, 0$ & r. & $r+, 1$ & r & rv & 01 & rا - نقص سلالات الأغنام ذات اللحم الوفير. \\
\hline$r r, r$ & rt & it & 11 & rq & $\varepsilon$. & $r \leqslant, \wedge$ & $\varepsilon \wedge$ & ـ ا- نقص سلالات الأغنام عالية الإنتاج. \\
\hline rr,o & $\leqslant 0$ & 19,7 & rV & $r \uparrow, \wedge$ & rv & r) & rq & 10 - -صعوبة نوفيق موسم الولادة مع موسم البرسيم. \\
\hline$\varepsilon r, 0$ & 7. & $r 0,0$ & $\varepsilon 9$ & $1 \cdot, 1$ & $1 \varepsilon$ & $1 \cdot, 9$ & 10 & 7 1- انتشار بعض الأمراض. \\
\hline
\end{tabular}


جدول V ا ـ ترتيب الخدمات الإرشادية تنازلياً وفقاً لارجة الاحتياج اليها

\begin{tabular}{|c|c|c|c|c|}
\hline \multicolumn{2}{|c|}{ 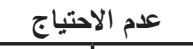 } & \multicolumn{2}{|c|}{ 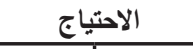 } & \multirow{2}{*}{ الخدمات الإرشاديـة } \\
\hline$\%$ & العدد & $\%$ & 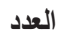 & \\
\hline $1 \mathrm{~V}, \varepsilon$ & $r \varepsilon$ & $\wedge r, r$ & $11 \varepsilon$ & 1- متابعة دورية للأغنام. \\
\hline $1 \wedge, 1$ & ro & 11,9 & $11 \pi$ & r- توفير مركزات الأعلاف بأسعار رخيصة. \\
\hline$r \leqslant, 7$ & $r \varepsilon$ & $v_{0}, \varepsilon$ & $1 \cdot \varepsilon$ & r- التوعية المستمرة بأهم التوصيات في مجال تربية الأغنام. \\
\hline$r_{0, \varepsilon}$ & ro & $V \varepsilon, 7$ & $1 . r$ & ع - عقد الاجتماعات الإرشادية للتوعية بالأساليب السليمة لرعاية الأغنام. \\
\hline ץ , I & צ & $V r, q$ & $1 . r$ & ه- التوعية بأساليب التغذية ومعدلاتها للأغنام. \\
\hline$r\urcorner, \wedge$ & rv & $\mathrm{VT}, \mathrm{r}$ & 1.1 & 7- توفير خدمات التلقيح الاصطناعي للأغنام. \\
\hline$r V, O$ & ra & $V Y, O$ & $1 \cdots$ & V- التدريب على الاكتشاف المبكر لأمراض الأغنام. \\
\hline rq & $\varepsilon$. & (1) & $9 \wedge$ & ^- التدريب على إعداد أعلاف غير تقليدية من بقايا المحاصيل. \\
\hline$\leqslant \vee, \uparrow$ & 77 & or,, 7 & VT & 9- توفير نشرات إرشادية بصورة سهلة ومستمرة. \\
\hline 07,0 & $\vee \wedge$ & $\varepsilon r, 0$ & 7. & • 1- توفير مجلة الإرشاد الزراعي. \\
\hline
\end{tabular}

r- أوضحت النتائج انخفاض تطبيق المبحوثين للتوصيات الفنية

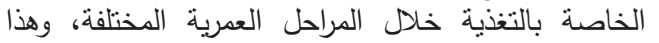

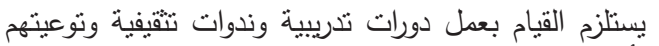

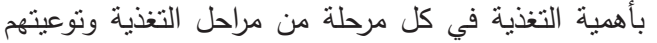

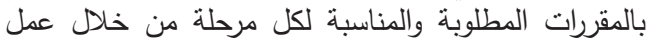

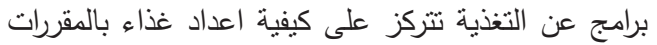

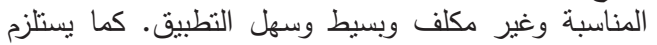

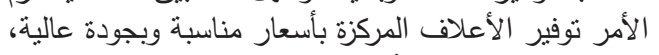

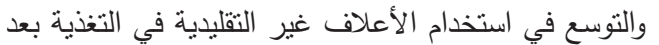
معالجتها وزيادة نسبة البروتين بها.

ع- الاهتمام بتوفير الخدمات الإرشادية التي يحتاجها المبحوثين

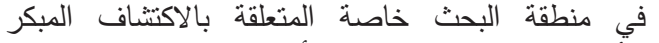

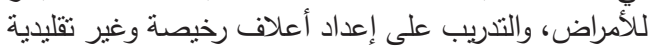
، مع التوعية بأساليب التغذية السليمة ومعدلاتها. لاعليا.

0- إزالة جميع المعوقات التي اسفر عنها البحث حتى يتمكن

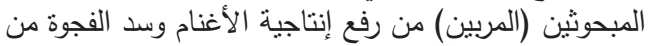

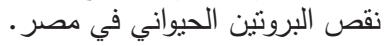

7- أظهرت النتائج عدم اعتماد غالبية المربين على جهاز الإرشاد

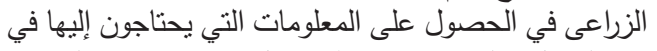

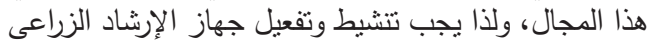
في مجال تربية ورعاية الأغنام.

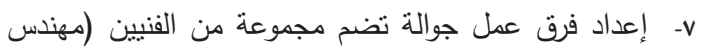
إرشاد حيواني، وطبيب بيطري، ومسئول عن الهندسة الونة الوراثية)

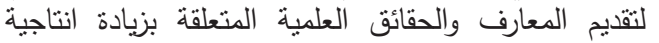

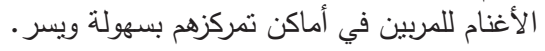

وتكثف هذه النتائج أن ثناثة أرباع المبحوثين مربين الأغنام

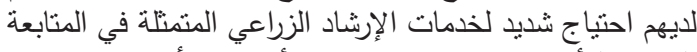

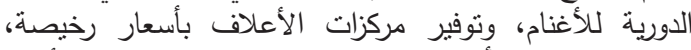

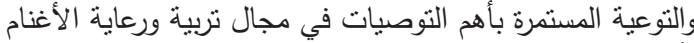

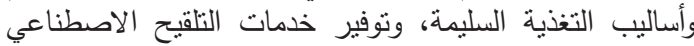

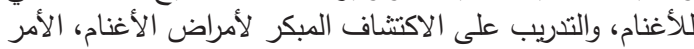

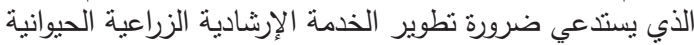

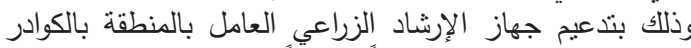

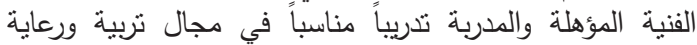

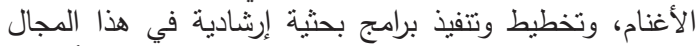

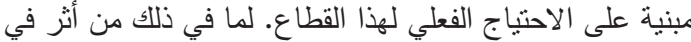

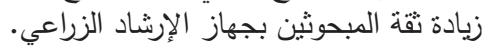

التوصبيات :

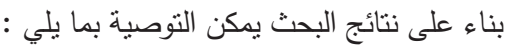

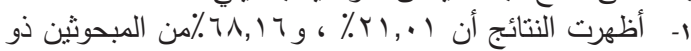

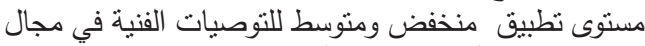
تربية ورعاية الأغنام، وهذا الأمر يستوجب التوني

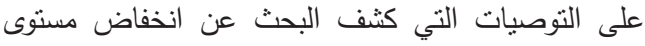

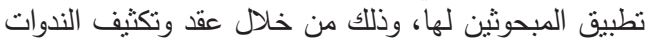

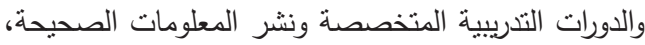

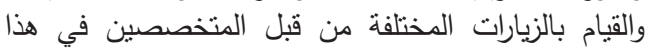
المجال للمربين وحثهم على الاتصال المستمر بهم.

r- بينت النتائج عدم معرفة غالبية المبحوثين بالتوصيات اللازمة

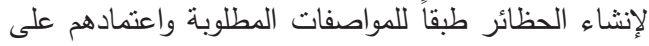

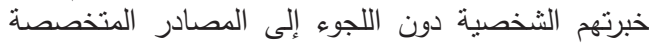

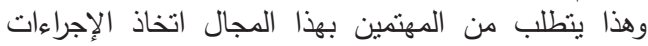

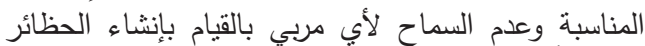

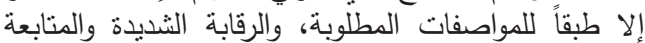

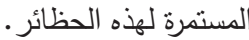




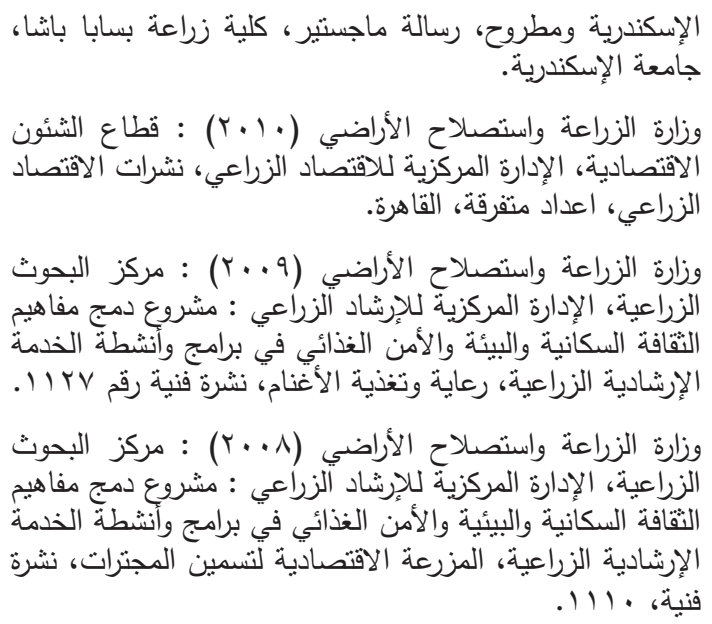

(Received: 3/ 9 /2018; accepted:15/10/2018)

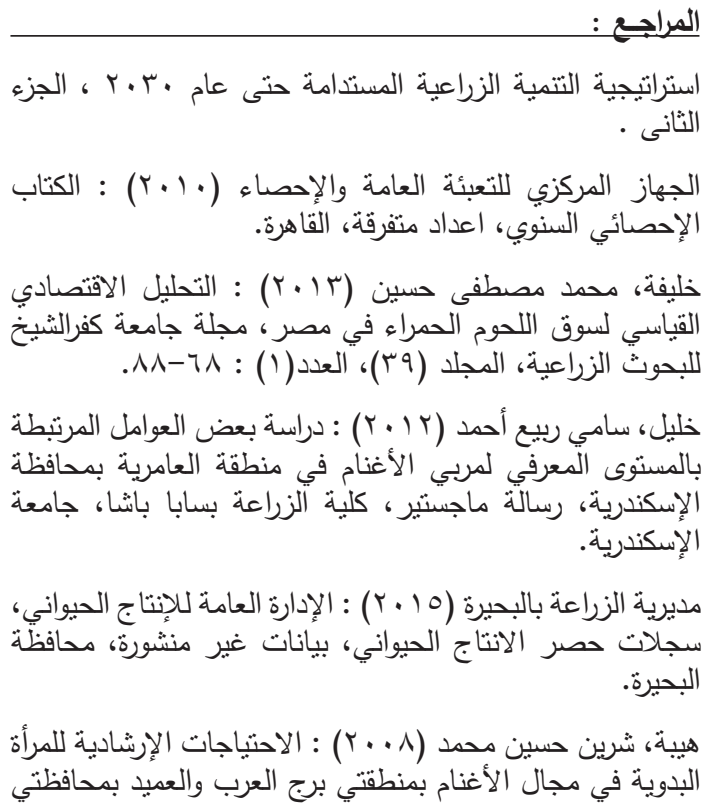

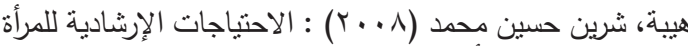

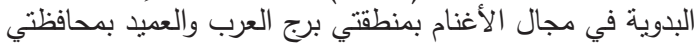

\section{Application of Breeders to Technical Recommendations in The Field of Raising and Caring for Sheep in Some Villages of Behira Governorate}

Tiesseer Bazina and Allam M Tantawy

Agricultural Extension and Rural Development Research Institute- Agricultural Research Center

$\mathbf{T}$

he research aimed to identifying the level of application of the breeders to the technical recommendations in the field of raising and caring sheep in the Behira Governorate. The largest center in the field of sheep breeding and caring was selected in Wadi al-Natroun. The center contains four main villages; the number of breeders in the four villages was 79 . The data were collected using the personal interview and used frequencies, percentages, means, and alpha coefficient .The main results were: About $\% \uparrow \lambda, 17$ of the respondents were medium application of technical recommendations in the field of sheep breeding and caring. Respondents resort to eleven sources to obtain information about sheep breeding and caring and there are four sources that have an advanced ranking were personal experience $(\%, q, \tau)$, other breeders $(\% \vee \neg, 1)$, neighbors and relatives $(\% \vee r, q)$ and the veterinary unit $(\% \vee, r)$. There were 17 obstacles faced by sheep breeders, the main obstacles facing them were the increase in the prices of concentrated feeds $(\% \vee r, r)$, the increase in the rental value of agricultural land $(\%\urcorner 9, \curlyvee)$ and the high costs of veterinary treatment $(\%\ulcorner\varepsilon, 0)$. Respondents need some extension services and the most needed services are the regular follow-up of sheep ( $\%$ r,$\tau)$, providing cheap feed concentrates $(\% \wedge, 9)$, and continuing awareness of the most important recommendations in the field of sheep breeding $(\% \vee, \varepsilon)$.

Key words: Application, Technical; Recommendations, Sheep; Breeding, Beheira Governorate 